\title{
Geocronologia e Geologia Isotópica dos Terrenos Pré-Cambrianos da Porção Sul-O riental do Estado de São Paulo
}

\author{
Cláudia Regina Passarelli ${ }^{1}$ (crpass@usp.br), Miguel Angelo Stipp Basei², Mario da Costa Campos Neto², \\ O swaldo Siga Júnior², Hélcio José dos Prazeres Filho ${ }^{3}$ \\ ${ }^{1}$ Centro de Pesquisas Geocronológicas - Instituto de Geociências - USP \\ R. do Lago 562, CEP 05508-080, São Paulo, SP, BRA \\ ${ }^{2}$ Departamento de Mineralogia e Geotectônica - Instituto de Geociências - USP, São Paulo, SP, BRA \\ 3Programa de Pós-Graduação em G eoquímica e G eotectônica - Instituto de Geociências - USP, São Paulo, SP, BRA
}

Palavras-chave: Neoproterozóico, domínios tectônicos, zonas de cisalhamento, rochas gnáissico-migmatíticas.

\section{RESUMO}

Na porção sul do Cinturão Ribeira, especificamente região sul-oriental do Estado de São Paulo, quatro domínios tectônicos distintos foram definidos, delimitados por importantes zonas de cisalhamento neoproterozóicas. O Domínio Embu, situado a norte da Zona de Cisalhamento Cubatão (ZCC), compreende metassedimentos parcialmente fundidos e granitos peraluminosos intrusivos, que são balizados por zonas de cisalhamento ENE e apresentam idades U-Pb em torno de $600 \mathrm{Ma}$, e idade TDM de 2,0 Ga. Rochas gnáissico-migmatíticas (612 Ma) e graníticas associadas (580 Ma) predominam no Domínio Mongaguá, limitadas a NW pela ZCC, e a sul pela Zona de Cisalhamento Itariri (ZCI), com idades TDM variadas, entre 1,7 e 2,2 Ga. O Domínio Registro é limitado a norte pelo Sistema de Cisalhamento Cubatão Itariri (SCCI) e a sul pela Zona de Cisalhamento Serrinha (ZCS), composto por rochas metassedimentares de alto grau e rochas graníticas com feições migmatíticas. Representa um terreno paleoproterozóico (1,9 - 2,2 Ga) fortemente afetado durante o Neoproterozóico (750 - $580 \mathrm{Ma})$. O Domínio Iguape é limitado a norte pela ZCS e compreende rochas graníticas, com cerca de $600 \mathrm{Ma}$, intrudidas em metassedimentos de baixo grau. Granitos semelhantes aos da Suíte intrusiva Serra do Mar ocorrem nos Domínios Registro e Iguape, com idades em torno de 580 Ma. Possivelmente, a justaposição destes domínios tectônicos ocorreu em épocas neoproterozóicas próximas: 1) a justaposição do Domínio Registro ao Embu, através de zona de cisalhamento EW, teve como época máxima 596 Ma; 2) granitos intrusivos no Domínio Embu, com cerca de 598 Ma, controlados pelo SCCI podem estar associados à justaposição do Domínio Mongaguá, aos Domínios Registro e Embu; 3) a época mais provável da colagem Domínio Iguape / Registro de 575 Ma é sugerida através de datações U-Pb (monazita) em protomilonito granítico da ZCS.

Keywords: Neoproterozoic, tectonic domains, shear zones, gneiss-migmatite rocks.

\section{ABSTRACT}

In the southeastern region of São Paulo State four major tectonic domains were defined. The Embu Domain, north of the Cubatão Shear Zone (CSZ), is composed of metasedimentary rocks, and peraluminous granites ( $c a$. $600 \mathrm{Ma}$ ), whose intrusion was controlled by E-NE shear zones, and which have model Nd TDM age around 2.0 Ga. Gneiss-migmatite rocks (612 Ma) and related granites (580 Ma) predominate in the Mongaguá Domain, which is limited by the Cubatão and Itariri shear zones. These rocks have different model Nd TDM ages between 1.7 and 2.2 Ga. The Registro Domain, between Cubatão - Itariri Shear System (CISS) and the Serrinha Shear Zone (SSZ), is formed by metasediments and granitic rocks with migmatitic features, and represents a paleoproterozoic domain $(1.9-2.2 \mathrm{Ga})$ intensely affected in Neoproterozoic times (750 - 580 Ma). Rocks of the Iguape Domain, limited to the north by the SSZ, include granites ( $\mathrm{ca}$. $600 \mathrm{Ma}$ ) and low grade metasediments. It is probable that all these tectonic blocks were juxtaposed during a short time interval at the end of Neoproterozoic. The joining of the Registro to the Embu Domain occurred at about 596 Ma along an E-W shear zone. The 598 Ma peraluminous granites of the Embu Domain may register the arrival of the Mongaguá Domain against the newly formed Registro-Embu Domain. The welding of the Iguape and Registro domains probably occurred at $575 \mathrm{Ma}$, as suggested by the U-Pb (monazite) age of the protomylonitic granites of the SSZ. 


\section{IN TRO DUÇÃO}

A porção sul-oriental do Estado de São Paulo constituise de compartimentos tectônicos delimitados por expressivas zonas de cisalhamento. Faz parte da Província Mantiqueira (Almeida et al., 1981), especificamente da porção sul do Cinturão Ribeira constituído por diferentes terrenos com características litológicas, geocronológicas e isotópicas distintas. A área de enfoque (Figura 1) é fundamental à compreensão do quadro geotectônico regional e oferece grande oportunidade de discussão sobre a continuidade dos terrenos localizados a sul, Domínios Curitiba e Paranaguá (Siga Jr., et al. 1995) e dos terrenos localizados a norte, pertencentes à Microplaca Serra do Mar (Campos Neto \& Figueiredo, 1995; Campos Neto, 2000).

A região estudada foi subdividida em quatro domínios tectônicos definidos por características litológicas, geoquímicas e isotópicas distintas (Passarelli et al., 2000). O Domínio Embu compreende a região a norte da Zona de Cisalhamento Cubatão (ZCC), o Domínio Mongaguá é delimitado pela ZCC a NW e a SSE pela Zona de Cisalhamento Itariri (ZCI), o Domínio Registro é limitado a norte pelo Sistema de Cisalhamento Cubatão Itariri (SCCI) e a sul pela Zona de Cisalhamento Serrinha (ZCS), que o separa do Domínio Iguape (Figura 2).

\section{DOMÍNIO EMBU}

Este compartimento corresponde ao Complexo Embu (Hasui et al., 1981), ao Bloco Embu (Dantas et al., 1987a), ao Terreno Acrescido Embu (Campos Neto \& Figueiredo, 1995) e ao Complexo Embu como parte do Terreno Juiz de Fora (Campos Neto, 2000). Na porção sudeste do Estado de São Paulo, o Domínio Embu compreende mica xisto, paragnaisse parcialmente migmatizado e quartzito (Complexo Embu) e xisto fino, filito e subordinadamente quartzito, metabasito e rocha cálcio-silicática (Sequiência Miracatu). Estas unidades são intrudidas por granitos cálcio-alcalinos de alto potássio e peraluminosos tardi-orogênicos (Dantas et al., 1987a).

A seqüência metassedimentar apresenta época de sedimentação ainda incerta. Núcleos migmatíticos, interpretados como embasamento das rochas supracrustais do Complexo Embu por Fernandes (1991), da região de São José dos Campos, apresentaram uma idade isocrônica Rb-Sr de $2473 \pm 46 \mathrm{Ma}$, e leucogranitos associados, prováveis leucossomas dos migmatitos, de $1497 \pm 46$ Ma (Tassinari, et al., 1988).

Na área de estudo, logo a norte da ZCC (Figura 2), rochas metassedimentares de médio a alto grau metamórfico apresentam-se intrudidas por corpos de muscovita-biotita

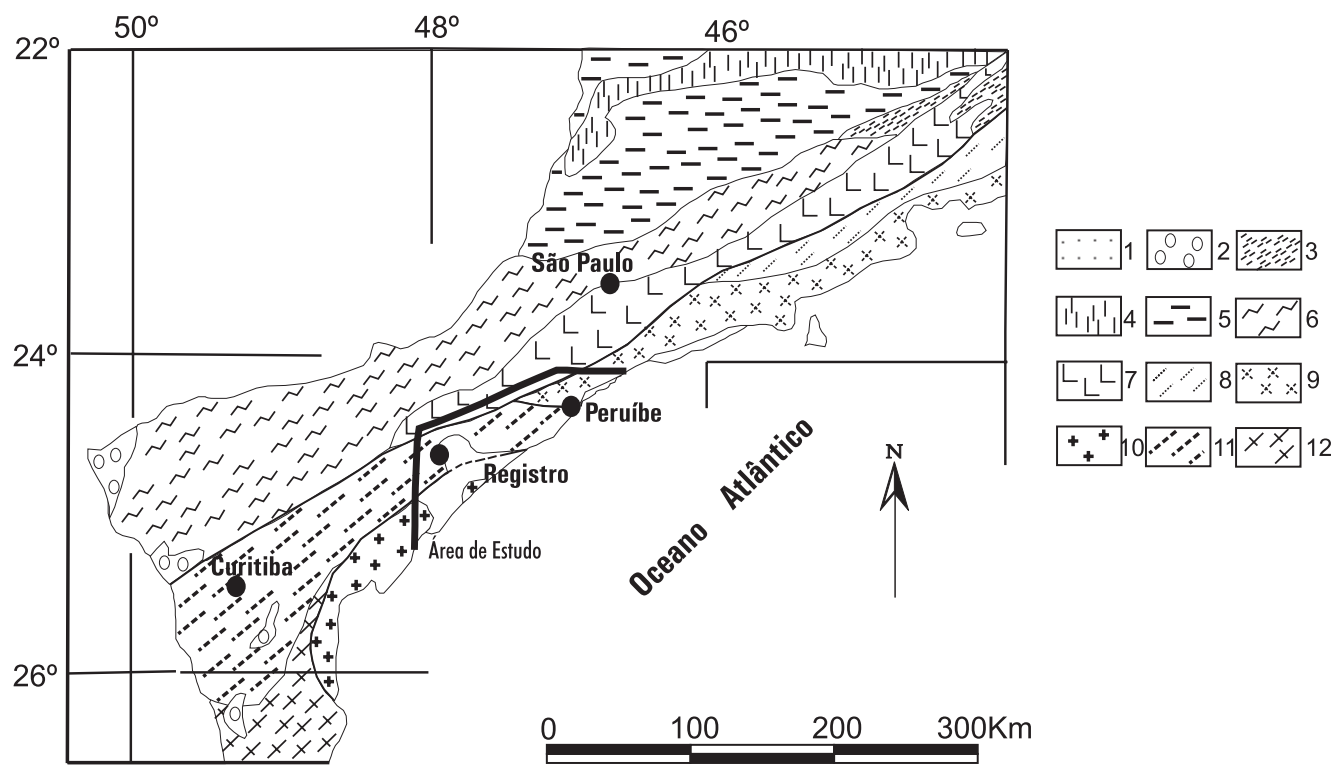

Figura 1. Esboço da compartimentação tectônica das regiões sudeste do Estado de SP e nordeste do PR, e localização da área (modificado de Campos Neto \& Figueiredo, 1995; Basei et al., 1999). 1. Cobertura Fanerozóica (Bacia do Paraná). 2. Bacias Neoproterozóicas/Eopaleozóicas. 3. Domínio Infracrustal Juiz de Fora. 4. Domínio Alto Rio Grande. 5. Domínio Socorro-Guaxupé. 6. Domínio Apiaí. 7. Domínio Supracrustal Embu. 8. Domínio Paraíba do Sul. 9. Domínio Serra do Mar. 10. Domínio Paranaguá. 11. Domínio Curitiba. 12. Domínio Luis Alves. 


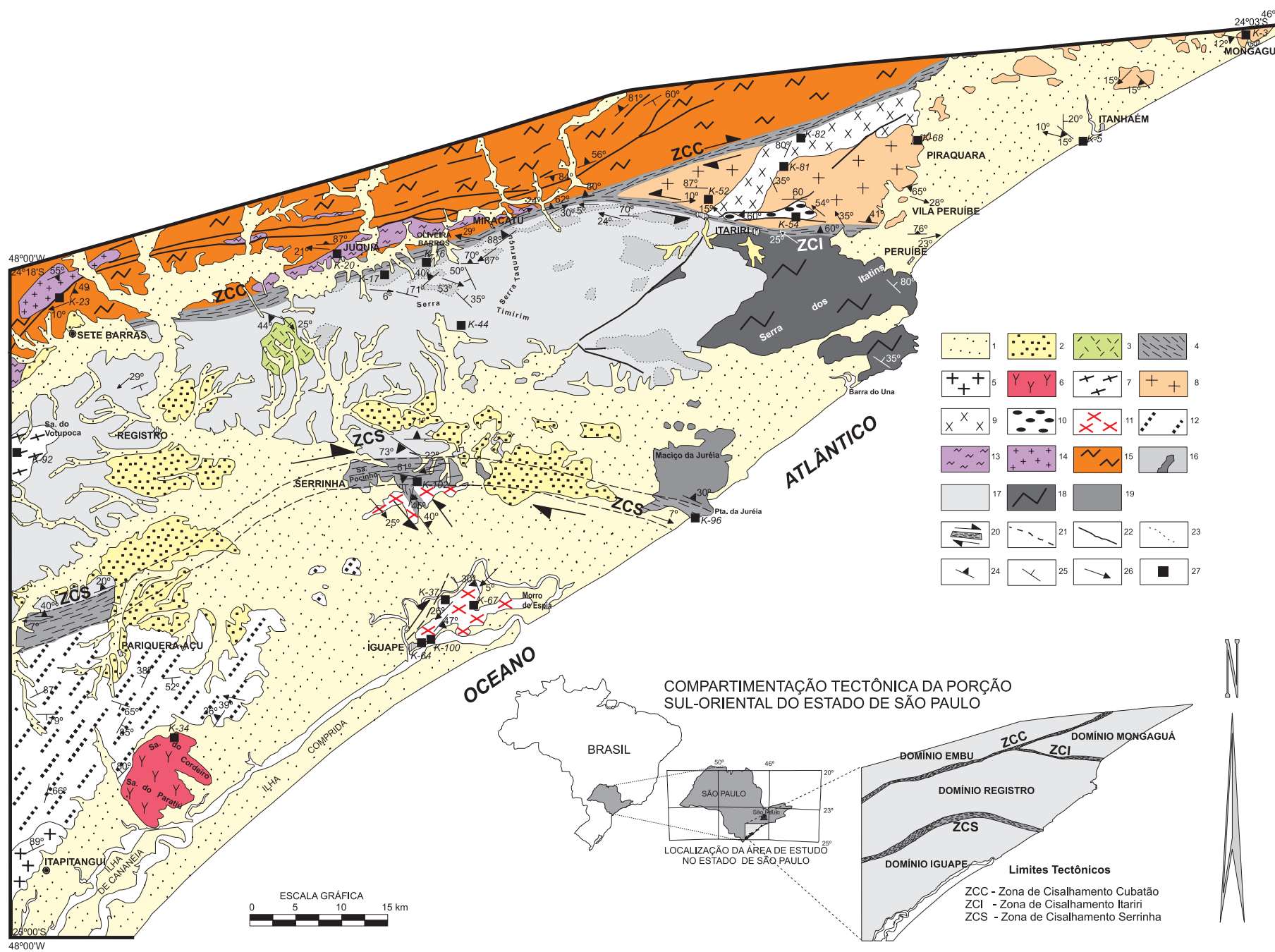

Figura 2. Mapa geológico da porção sul-oriental do Estado de São Paulo. 1. Sedimentos Quaternários. 2. Sedimentos Terciários. 3. Complexo Alcalino de J uquiá (Cretáceo). 4. SCCI e ZCS: rochas miloníticas (600 - 570 Ma). Suíte Granítica Serra do Mar (c. 580 Ma): 5. Granito Itapitangui. 6. Granito Serra do Cordeiro. 7. Granito Serra do Votupoca. Domínio Mongaguá: 8. Domínio granito-gnáissico-migmatítico (c. 615 - 580 Ma). 9. Granito Areado (c. 610 580 Ma). 10. Granito Ribeirão do Oleo (c. 580 Ma). Domínio Iguape: 11. Granito Iguape (c. 600 Ma). 12. Metassedimentos Iguape (<2200 Ma). Domínio Embu: 13. Granito Juquiá (c. $600 \mathrm{Ma}$ ). 14. Granito Sete Barras (c. $630 \mathrm{Ma})$. 15. Metassedimentos (< 1600 - 1800 Ma). Domínio Registro: 16. Domínio granito-gnáissico-migmatítico (2100 - 580 Ma). 17. Domínio Gnáissico (2200 - 580 Ma). 18. Complexo Itatins (2200 - 580 Ma). 19. Juréia (> 750 Ma). 20. Zonas de Cisalhamento transcorrentes. 21. Falhamento inferido. 22. Lineamentos. 23. Contato geológico gradacional. 24. Foliação milonítica. 25. Foliação principal. 26. Lineação mineral. 27. Afloramento com análises isotópicas e/ou datação U-Pb / K-Ar. 
monzogranito peraluminoso, denominados informalmente de Granito Juquiá e Sete Barras por Passarelli (2001).

Faixas miloníticas cortam o Domínio Embu e definem importantes lineamentos subparalelos às ZCC e ZCI, com direções em torno de EW e mergulhos subverticais. Falhamentos transcorrentes de movimentação dextral afetam as rochas metassedimentares e balizam diversos stocks graníticos. Os granitos de Sete Barras e Juquiá estão orientados nas faixas de cisalhamento (orientação do eixo maior dos stocks em torno de N70E), e mostram formas estiradas, notadamente o Granito Juquiá. Normalmente apresentam textura protomilonítica, caracterizada pela orientação de porfiroclastos de feldspato potássico com formato sigmoidal e orientação dos minerais máficos.
Idades U-Pb (monazita) de $598 \pm 8$ Ma para o Granito Juquiá, e $631 \pm 23$ Ma para o Granito Sete Barras (Figura 3, Tabela 1) são interpretadas como épocas de formação destas rochas, possivelmente por fusão de fontes crustais.

As idades em torno de $750 \mathrm{Ma}$ obtidas pelas frações de zircão analisadas (Granito Sete Barras em $739 \pm 63$ Ma e Granito Juquiá em $761 \pm 2$ Ma, Figura 3) podem refletir heranças isotópicas por tratarem-se de granitos crustais. Entretanto, analisando-se a distribuição das frações de zircão analisadas, cujo alinhamento permite a determinação de uma idade intercepto superior, a possibilidade destas idades representarem a época de cristalização destes granitos e àquelas obtidas em monazitas ( $c a .600$ e $620 \mathrm{Ma}$ ) registrarem eventos térmicos posteriores, não pode ser descartada.

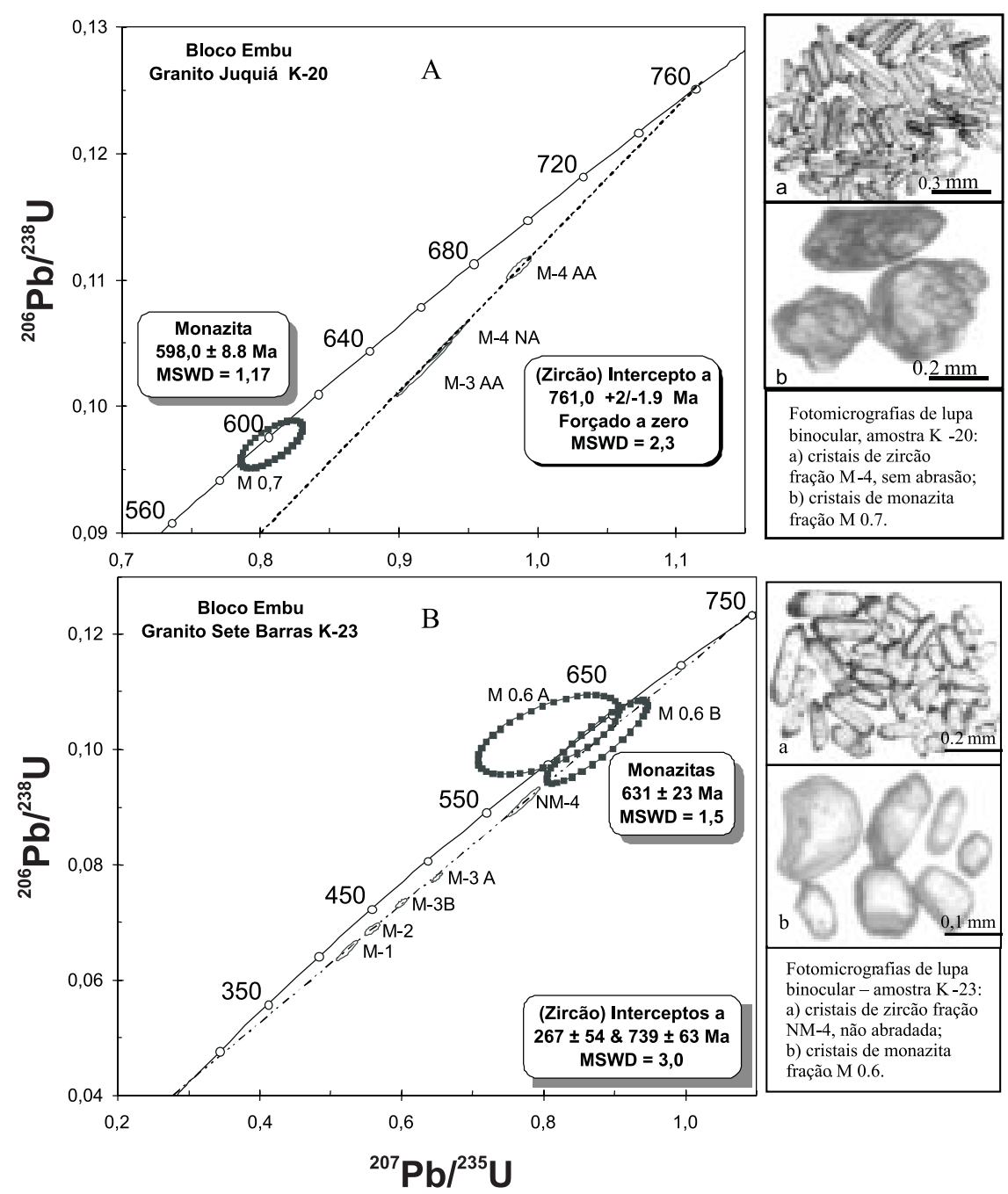

Figura 3. Diagramas Concórdia ${ }^{207} \mathrm{~Pb} /{ }^{235} \mathrm{U} \times{ }^{206} \mathrm{~Pb} /{ }^{238} \mathrm{U}$ em zircão e monazita. Domínio Embu. A) Granito Juquiá. B) Granito Sete Barras. 
O Granito Juquiá apresentou uma idade modelo TDM de 1984 Ma e valores de $\boldsymbol{E}_{\mathrm{Nd}(\mathrm{t})}$ e $\boldsymbol{\varepsilon}_{\mathrm{Nd}(0)}$ respectivamente de $-14,71$ e -22,61 (Tabela 2), indicando uma origem crustal para os protólitos destes granitos, e um tempo relativamente longo de residência crustal. Os dados indicam a composição isotópica da área fonte das rochas que originaram estes granitos, considerando-se sua geração a partir da fusão de rochas metassedimentares. A origem destas rochas a partir de reservatórios crustais é corroborada pelo valor de $\left(\mathrm{Sr}^{87} / \mathrm{Sr}^{86}\right) \mathrm{i}_{(600 \mathrm{Ma})}$ em torno de 0,727 (Tabela 3) obtido no Granito Juquiá.

A época em torno de $750 \mathrm{Ma}$, obtida pelo método $\mathrm{Rb}-\mathrm{Sr}$ em xistos do Complexo Embu (Vieira \& Tassinari, 1988) foi associada, por Fernandes (1991), à fase metamórfica principal do Complexo Embu que atingiu grau forte (migmatização in situ) e grau médio (zona da sillimanita). Adicionalmente, através de datações $\mathrm{U}-\mathrm{Pb}$ (monazitas) realizadas em rochas gnáissicas, a época em torno de $790 \mathrm{Ma}$ (Vlach, 2001) representa o evento metamórfico principal deste domínio e indica uma fase associada a um processo tectônico convergente.

Na região de São Lourenço da Serra (SP), ortognaisses miloníticos, com estruturas migmatíticas preservadas, apresentaram idades $\mathrm{Rb}-\mathrm{Sr}$ (RT) de $770 \mathrm{Ma}$, com $\mathrm{Ri}=0,722$ (Cordani et al., 2000), semelhantes às idades em U-Pb em zircões, e a $\mathrm{Ri}\left(\mathrm{Sr}^{87} / \mathrm{Sr}^{86}\right)$ obtidas neste trabalho. No entanto, através de análises SHRIMP, os autores observaram populações de zircões bem heterogêneas, com idades em torno de 2000, 800 e $660 \mathrm{Ma}$, interpretados respectivamente como zircões herdados, magmáticos e metamórficos.

Adicionalmente, o granito gnáissico Serra dos Lopes, localizado a sul da Zona de Cisalhamento Taxaquara, próximo à cidade de Piedade (SP) forneceu uma idade U-Pb (zircão) de $788 \pm 2$ Ma (Leite, 2003), interpretada como a melhor estimativa da época da cristalização magmática destes ortognaisses, considerados como encaixantes dos granitos sin-orogênicos do Batólito Agudos Grandes.

A partir dos dados existentes nota-se o registro do período Criogeniano no Domínio Embu, apesar de ainda impreciso. De modo geral, podemos considerar que entre aproximadamente 800 e 750 Ma um importante evento metamórfico e magmático deve ter ocorrido neste terreno.

De modo preliminar, devido aos erros analíticos, a idade obtida em monazitas para o Granito Sete Barras, pode estar associada à fase sin-colisional deste setor do Cinturão Ribeira, em torno de $620 \mathrm{Ma}$, (Janasi, 1999; Hackspacher et al., 2000) ou $610 \mathrm{Ma}$ (Janasi et al., 2001) responsável por importante geração de magmatismo cálcio-alcalino. Por outro lado, a idade de formação do Granito Juquiá, obtida em monazitas, possivelmente está associada ao desenvolvimento das zonas de cisalhamento que balizam estes corpos graníticos. Esta idade, em torno de $600 \mathrm{Ma}$, pode ser correlacionada à fase tardi-colisional deste setor do Cinturão Ribeira (Janasi et al., 2001), responsável pela tectônica de escape lateral com desenvolvimento de diversas zonas de cisalhamento NE-SW e colocação de corpos graníticos (Hackspacher et al., 2000).

\section{DOMÍNIO REGISTRO}

Representado principalmente por rochas granitognáissicas migmatíticas, é delimitado a norte pelo SCCI e a sul pela ZCS (Figura 2). Corresponde cartograficamente ao Complexo Gnáissico-Migmatítico e Suíte Granítica de Facies Migmatítica de Dantas et al. (1987b) e abrange os paragnaisses do Maciço da Juréia, aqui correlacionados aos paragnaisses da Seqüência Cachoeira (Silva et al., 1978; Dantas et al., 1987a, b). Esta seqüência compreende kinzigitos e gnaisses kinzigíticos aflorantes na região do Maciço de Itatins (Picanço et al., 1998).

O domínio gnáissico-migmatítico compreende rochas granitóides (monzogranitos a granodioritos) complexamente inter-relacionadas com material diorítico, mesocrático, comumente desenvolvendo estruturas migmatíticas heterogêneas. Apresenta uma estruturação predominantemente NW, entretanto mostra forte influência do SCCI, com estruturas de direção EW e NE. Parte das feições observadas, conseqüência de processos de mingling e mixing entre dois magmas distintos, acarretou no desmembramento de diques sin-intrusivos e formação de enclaves.

As rochas gnáissico-migmatíticas do Domínio Registro apresentaram idades $\mathrm{U}-\mathrm{Pb}$ em zircões extremamente discordantes, em posição intermediária entre os interceptos inferior e superior. Os resultados analíticos obtidos apresentam-se listados na Tabela 1.

Em anfibólio-biotita granodiorito aflorante na região de Oliveira Barros (W do município de Miracatu) obteve-se uma idade, intercepto superior, de $1894 \pm 26$ Ma através do alinhamento de frações de zircão extremamente discordantes (Figura 4). No afloramento em questão, a rocha granitóide preserva a foliação magmática e apresenta dique sinintrusivo máfico rompido, gerando enclaves arredondados (Foto 1). O posicionamento intermediário das frações, entre os interceptos, deve refletir zircões que foram parcialmente rejuvenescidos, e a idade sugerida pelo intercepto superior, a idade mínima de cristalização desta rocha e conseqüentemente do processo de mingling entre os magmas granodiorítico e diorítico.

Em áreas caracterizadas pela presença de rochas híbridas, onde feições gnáissicas e migmatíticas são comuns (Foto 2), com enclaves dioríticos parcialmente assimilados pelo material granítico, observa-se a tendência do registro de idades paleoproterozóicas e neoproterozóicas. Nesta região, onde o mixing é evidente, biotita-monzogranitos mesocráticos apresentam uma idade intercepto superior de 


\begin{tabular}{|c|c|c|c|c|c|c|c|c|c|c|c|c|c|}
\hline \multirow[b]{2}{*}{ Unidade } & \multirow[b]{2}{*}{ Amostra } & \multirow[b]{2}{*}{$\begin{array}{c}\text { Mineral } \\
\text { Analisado } \\
\end{array}$} & \multirow[b]{2}{*}{$\begin{array}{c}\text { Fração } \\
\text { Magnética }\end{array}$} & \multirow[b]{2}{*}{$\begin{array}{l}\text { Peso } \\
\text { (mg) }\end{array}$} & \multirow[b]{2}{*}{$\begin{array}{c}U \\
\text { (ppm) }\end{array}$} & \multirow[b]{2}{*}{$\begin{array}{c}\mathrm{Pb} \\
(\mathrm{ppm})\end{array}$} & \multicolumn{4}{|c|}{ Razões Isotópicas } & \multicolumn{3}{|c|}{ Idades (Ma) } \\
\hline & & & & & & & $\begin{array}{l}\mathrm{Pb}^{206} \mathrm{I} \\
\mathrm{Pb}^{204} \\
\end{array}$ & $\begin{array}{c}\mathrm{Pb} \mathrm{Pb}^{207} / \mathrm{U}^{235} \\
-E \text { Erro\% }(2 \sigma)\end{array}$ & $\begin{array}{c}\mathrm{Pb}^{206} / \mathrm{U}^{238} \\
-E \text { Erro\% }(2 \sigma)\end{array}$ & 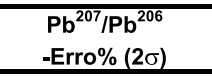 & $\begin{array}{l}\mathrm{Pb}^{207} \mathrm{I} \\
\mathrm{U}^{235}\end{array}$ & $\begin{array}{l}\mathrm{Pb}^{206} \mathrm{I} \\
\mathrm{U}^{238} \\
\end{array}$ & $\begin{array}{l}\mathrm{Pb}^{207} \mathrm{I} \\
\mathrm{Pb}^{206}\end{array}$ \\
\hline \multicolumn{14}{|l|}{ Bloco Embu } \\
\hline & & zircão & M-3аa & 0,084 & 1720 & 189 & 1240,5 & $0,918054-1,76$ & $0,102949-1,76$ & $0,0646764-0,157$ & 661 & 632 & $764 \pm 3$ \\
\hline \multirow{6}{*}{$\begin{array}{l} \\
\text { Granito } \\
\text { Sete Barras }\end{array}$} & & monazita & $M(0,7)$ & 0,009 & 522 & 808 & 193,8 & $0,807472-2,29$ & $0,0970091-1,59$ & $0,060369-1,64$ & 601 & 597 & $617 \pm 35$ \\
\hline & \multirow{5}{*}{$\mathrm{K}-23$} & zircão & $M-1$ & 0,021 & 272 & 20 & 326,8 & $0,523165-2,35$ & $0,0651211-2,19$ & $0,058266-0,827$ & 427 & 407 & $540 \pm 18$ \\
\hline & & zircão & $\mathrm{M}-2$ & 0,05 & 226 & 18 & 400,2 & $0,558277-1,58$ & $0,0687619-1,22$ & $0,0588844-0,995$ & 450 & 429 & $563 \pm 22$ \\
\hline & & zircão & $M-3 A$ & 0,057 & 287 & 24 & 724,9 & $0,650147-0,924$ & $0,0778242-0,829$ & $0,0605893-0,405$ & 509 & 483 & $625 \pm 9$ \\
\hline & & monazita & $M(0,6) A$ & 0,0025 & 274 & 913 & 33,487 & $0,806374-10,1$ & $0,1025730-5,52$ & $0,057017-7,96$ & 600 & 629 & $492 \pm 180$ \\
\hline & & monazita & $M(0,6) B$ & 0,0014 & 693 & 1306 & 83,284 & $0,874922-6,61$ & $0,1013340-5,79$ & $0,06262-3,08$ & 638 & 622 & $695 \pm 66$ \\
\hline \multicolumn{14}{|l|}{ Bloco Registro } \\
\hline & & zircão & NM-1aa & 0,36 & 1263 & 107 & 3642,9 & $1,24414-1,1$ & $0,0799312-0,948$ & $0,112889-0,496$ & 821 & 496 & $1846 \pm 9$ \\
\hline Gr. Re & & zircão & $\mathrm{M}-3$ & 0,091 & 444 & 93 & 5203,3 & $3,16498-0,946$ & $0,197853-0,943$ & $0,116018-0,0756$ & 1449 & 1164 & $1896 \pm 1$ \\
\hline \multirow[t]{3}{*}{ Oliveira Barros } & $\mathrm{K}-16$ & zircão & M-4aa & 0,5 & 529 & 114 & 1583,3 & $3,13836-1$ & $0,197998-0,931$ & $0,114958-0,325$ & 1442 & 1165 & $1879 \pm 6$ \\
\hline & & zircão & M-4 & 0,086 & 393 & 87 & 3115,2 & $3,28181-0,653$ & $0,206296-0,65$ & $0,115378-0,056$ & 1477 & 1209 & $1886 \pm 1$ \\
\hline & & zircão & NM-4aa & 0,091 & 395 & 87 & 2082,3 & $3,234-0,628$ & $0,204367-0,625$ & $0,11477-0,0621$ & 1465 & 1199 & $1876 \pm 1$ \\
\hline & & zircão & M-5aa & 0,083 & 155 & 35 & 705,3 & $3,20363-0,649$ & $0,204125-0,618$ & $0,113827-0,197$ & 1458 & 1197 & $1861 \pm 4$ \\
\hline Juréia & K-96 & monazita & $\mathrm{M}(0,6)$ & 0,0024 & 4218 & 2024 & 1149,4 & $1,09655-0,855$ & $0,123517-0,822$ & $0,064387-0,228$ & 752 & 751 & $754 \pm 5$ \\
\hline Bloco Mongagi & & & & & & & & & & & & & \\
\hline Gn Mongaauá & $K-3$ & zircão & M-4aa A & 0,023 & 171 & 20 & 630 & $0,804876-0,714$ & $0,0972167-0,552$ & $0,0600463-0,425$ & 600 & 598 & $605 \pm 9$ \\
\hline Gn. Miongagua & $\mathrm{K}-3$ & zircão & $M-4 a$ & 0,086 & 211 & 24 & 1152 & $0,827404-0,674$ & $0,099540-0,658$ & $0,6028610-0,142$ & 612 & 612 & $614 \pm 3$ \\
\hline & & zircão & $\mathrm{M}-2$ & 0,099 & 378 & 42 & 1210,2 & $1,12002-0,84$ & $0,110379-0,703$ & $0,0735932-0,451$ & 763 & 675 & $1030 \pm 9$ \\
\hline Gr. Itariri & K-52 & & M-2aa & 0,087 & 747 & 85 & 920,5 & $1,10951-0,823$ & $0,109611-0,812$ & $0,0734133-0,135$ & 758 & 670 & $1025 \pm 3$ \\
\hline & & zircão & $M-3$ & 0,082 & 343 & 43 & 911,2 & $1,35383-0,871$ & $0,121103-0,847$ & $0,0810789-0,199$ & 869 & 737 & $1223 \pm 4$ \\
\hline & & zircão & $\mathrm{M}-2$ & 0,099 & 319 & 36 & 1199,2 & $0,986403-0,58$ & $0,110379-0,56$ & $0,064814-0,149$ & 697 & 675 & $768 \pm 3$ \\
\hline Gr. Itariri & $K-68$ & & M-4 & 0,095 & 244 & 29 & 597,1 & $1,0166-0,708$ & $0,111739-0,68$ & $0,0659852-0,195$ & 712 & 683 & $806 \pm 4$ \\
\hline & & o & NM-4 & 0,079 & & 36 & 1715,9 & $1,0923-0,635$ & $3-0,617$ & $0,0685228-0,149$ & 750 & 705 & $884 \pm 3$ \\
\hline & & zircão & $a(N M 1,5)$ & 0,034 & 406 & 45 & 1318,9 & $1,12216-0,738$ & $0,109383-0,724$ & $0,0744053-0,138$ & 764 & 669 & $1053 \pm 3$ \\
\hline Gr. R. Óleo & K-54 & zircão & M-3аa & 0,054 & 37 & 0 & 152,9 & $2,70985-2,43$ & $0,174292-2,42$ & $0,112763-0,337$ & 1331 & 1036 & $1844 \pm 6$ \\
\hline & & & & 0,085 & 423 & 44 & 903,3 & $0,865788-0,585$ & $0,097355-0,567$ & $0,0644987-0,141$ & 633 & 599 & $758 \pm 3$ \\
\hline Bloco Iguape & & & & & & & & & & & & & \\
\hline & & $z i$ & & & 7 & 56 & 2243 & $-0,918$ & 382 & $-0,253$ & 50 & 489 & $599 \pm 5$ \\
\hline & & & $\mathrm{M}-2$ & 0,084 & 753 & 73 & 1247,9 & $0,644946-0,543$ & $0,0786439-0,531$ & $0,0594781-0,111$ & 505 & 488 & $585 \pm 2$ \\
\hline Gr. Votupoca & K-92 & & $M-3$ & 0,078 & 667 & 63 & 1482 & $0,627909-0,563$ & $0,0767868-0,551$ & $0,0593074-0,115$ & 495 & 477 & $578 \pm 3$ \\
\hline & & zircão & M-4 & 0,076 & 766 & 79 & 1331,7 & $0,686814-0,678$ & $0,0837716-0,669$ & $0,0594622-0,108$ & 531 & 519 & $584 \pm 2$ \\
\hline
\end{tabular}

aa: frações abradadas. 
Tabela 2. Dados analíticos obtidos pela sistemática Sm-Nd.

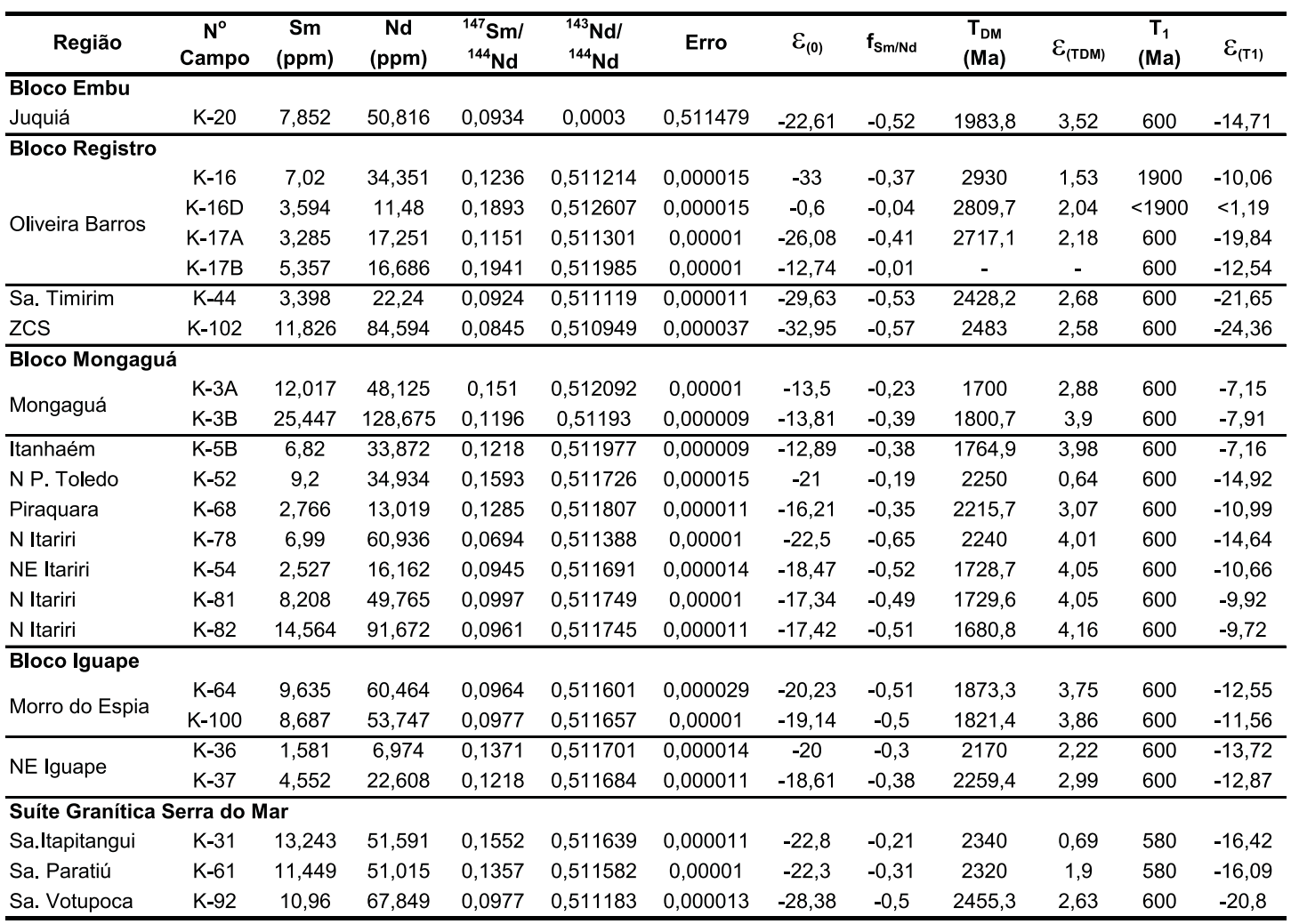

Tabela 3. Dados analíticos obtidos pela sistemática Rb-Sr.

\begin{tabular}{|c|c|c|c|c|c|c|c|c|c|c|c|}
\hline $\begin{array}{l}\text { Região / } \\
\text { Unidade }\end{array}$ & $\mathrm{N}^{\circ}$ Campo & $\begin{array}{c}\mathbf{R b} \\
(\mathrm{ppm})\end{array}$ & $\begin{array}{c}\mathrm{Sr} \\
(\mathrm{ppm})\end{array}$ & ${ }^{87} \mathrm{Rb} /{ }^{86} \mathrm{Sr}$ & ${ }^{87} \mathrm{Sr} /{ }^{86} \mathrm{Sr}$ & $\varepsilon_{(0)}$ & $\begin{array}{c}T_{\mathrm{DM}} \\
(\mathrm{Ma})\end{array}$ & $\varepsilon_{(\mathrm{TDM})}$ & $\begin{array}{c}\mathrm{T}_{1} \\
(\mathrm{Ma})\end{array}$ & $\varepsilon_{(\mathrm{T} 1)}$ & RE - T1 \\
\hline \multicolumn{12}{|l|}{ Bloco Embu } \\
\hline Juquiá & $\mathrm{K}-20$ & 211 & 244 & 2,513 & 0,748648 & 626,66 & 1312,60 & $-22,68$ & 600 & 331,7 & 0,72715 \\
\hline \multicolumn{12}{|l|}{ Bloco Registro } \\
\hline \multirow{2}{*}{ Oliveira Barros } & $\mathrm{K}-17 \mathrm{~A}$ & 112 & 395 & 0,822 & 0,724396 & 282,41 & 1985,90 & $-18,22$ & 600 & 192,7 & 0,71736 \\
\hline & K-17B & 113 & 271 & 1,209 & 0,726446 & 311,51 & 1451,30 & $-21,76$ & 600 & 174,8 & 0,7161 \\
\hline Sa. Timirim & $\mathrm{K}-44$ & 163 & 365 & 1,296 & 0,734826 & 430,46 & 1814,00 & $-19,36$ & 600 & 283,3 & 0,72374 \\
\hline \multicolumn{12}{|c|}{ Bloco Mongaguá } \\
\hline \multirow{2}{*}{ Mongaguá } & $\mathrm{K}-3 \mathrm{~A}$ & 216 & 463 & 1,352 & 0,719837 & 217,70 & 941,90 & $-25,11$ & 600 & 63,49 & 0,70827 \\
\hline & $\mathrm{K}-3 \mathrm{~B}$ & 180 & 244 & 2,139 & 0,726401 & 310,87 & 807,60 & $-25,99$ & 600 & 59,94 & 0,70802 \\
\hline Itanhaém & $\mathrm{K}-5 \mathrm{~B}$ & 49 & 755 & 0,188 & 0,709698 & 73,78 & 3665,40 & $-6,85$ & 600 & 60,94 & 0,70809 \\
\hline Gr. Itariri & K-52 & 401 & 57 & 18,94 & 0,89565 & 2713,27 & 655,10 & $-26,99$ & 600 & 204,68 & 0,71821 \\
\hline Gr. Itariri & K-68 & 94 & 157 & 1,612 & 0,73902 & 489,99 & 1514,80 & $-21,34$ & 600 & 289,08 & 0,72415 \\
\hline Gr. Itariri & $\mathrm{K}-78$ & 175 & 510 & 0,924 & 0,719289 & 209,92 & 1255,00 & $-23,06$ & 600 & 99,18 & 0,71078 \\
\hline Rib. Óleo & K-54 & 149 & 559 & 0,772 & 0,714874 & 147,25 & 1214,90 & $-23,32$ & 600 & 63,47 & 0,70827 \\
\hline Gr. Areado & $\mathrm{K}-81$ & 213 & 354 & 1,745 & 0,729698 & 357,67 & 1128,70 & $-23,89$ & 600 & 155,78 & 0,71477 \\
\hline Gr. Areado & $\mathrm{K}-82$ & 225 & 260 & 2,511 & 0,735365 & 438,11 & 939,50 & $-25,13$ & 600 & 143,15 & 0,71388 \\
\hline \multicolumn{12}{|l|}{ Bloco Iguape } \\
\hline \multirow{2}{*}{ Morro do Espia } & K-64 & 202 & 221 & 2,652 & 0,733248 & 408,06 & 832,50 & $-25,83$ & 600 & 95,97 & 0,71056 \\
\hline & $\mathrm{K}-100$ & 197 & 318 & 1,797 & 0,728321 & 338,13 & 1041,10 & $-24,46$ & 600 & 129,97 & 0,71295 \\
\hline NE Iguape & $\mathrm{K}-37$ & 283 & 75 & 11,029 & 0,808069 & 1470,11 & 675,20 & $-26,85$ & 600 & 140,68 & 0,7137 \\
\hline \multicolumn{12}{|c|}{ Suíte Granítica Serra do Mar } \\
\hline Sa. Votupoca & $\mathrm{K}-92$ & 346 & 156 & 6,46 & 0,772035 & 958,62 & 761,90 & $-26,29$ & 600 & 184,2 & 0,71676 \\
\hline
\end{tabular}


$2197 \pm 41$ Ma, interpretada como provável época de cristalização do protólito desta rocha (Figura 5). A idade obtida em intercepto inferior de $580 \pm 24 \mathrm{Ma}$, apesar de imprecisa, é interpretada como época de importante evento térmico que propiciou a migmatização intensa na região, e neoformação de cristais de zircão.

O paragnaisse milonítico aflorante no Maciço da Juréia (Foto 3) apresentou uma idade U-Pb em monazita concordante de $752 \pm 4 \mathrm{Ma}$ (Figura 6). Esta idade é interpretada como época de importante evento metamórfico, registrado em rochas metassedimentares da porção E do Domínio Registro, associado a uma paragênese que atingiu a facies anfibolito alto (Azevedo Sobrinho, 1995). Importante fase de deformação, em torno de $720 \pm 30 \mathrm{Ma}$ (Rb-Sr, RT, Picanço, 1994), está também registrada nas rochas do Complexo Itatins e da Seqüência Cachoeira.

As idades TDM obtidas para as rochas graníticas do Domínio Registro (Tabela 2), indicam duas épocas principais de diferenciação de seus protólitos do manto, entre 2,7 - 2,9 Ga e 2,4 Ga. O conjunto das rochas analisadas apresentou valores negativos de $\boldsymbol{\varepsilon}_{\mathrm{Nd}}$ distintos, $\boldsymbol{\varepsilon}_{\mathrm{Nd}(t)}$ de -10 para $\mathrm{T}=1900 \mathrm{Mae} \varepsilon_{\mathrm{Nd}(t)}$ entre $-12 \mathrm{e}-24$ para $\mathrm{T}=600 \mathrm{Ma}$ (Tabela 2), indicando contribuição a partir de fontes crustais distintas na geração destas rochas, bem como, períodos de residência crustal distintos.

Em local onde a mistura mecânica (mingling) entre o material máfico e félsico prevalece (Foto 1), a rocha granítica (K-16) e seu enclave (K-16D) apresentam diferenças isotópicas marcantes (Tabela 2), com valores de $\boldsymbol{\varepsilon}_{\mathrm{Nd}(t)}$ de -10,06 (granitóide) e + 1,19 ${ }_{(\mathrm{t} \leq 1900 \mathrm{Ma})}$ (enclave) indicativos de contribuição a partir de fontes crustais e mantélicas, respectivamente. Por outro lado, onde o mixing entre os materiais é mais evidente (K-17, Foto 2), os enclaves máficos (K17B) apresentam características isotópicas evidentes de contribuição crustal, com valores de $\boldsymbol{E}_{\mathrm{Nd}(\mathrm{t})}$ negativos (Tabela 2).

A razões isotópicas de $\left(\mathrm{Sr}^{87} / \mathrm{Sr}^{86}\right)$ i obtidas pela sistemática $\mathrm{Rb}$-Sr (Tabela 3) foram semelhantes entre as porções graníticas e dioríticas nas regiões onde o mixing prevalece, sugerindo contribuição crustal na geração destas rochas, e possivelmente homogeneização isotópica entre os distintos materiais, ou seja, ocorrência de locais onde houve forte interação entre os magmas e conseqüentemente um alto grau de hibridização entre os materiais (Perugini et al., 2002).

Em diagrama de $\varepsilon_{\mathrm{Sr}}$ x $\varepsilon_{\mathrm{Nd}}$, para t $=600 \mathrm{Ma}$ (Figura 7), as rochas do Domínio Registro tendem a formar um trend no quadrante inferior direito, este indicativo de contribuição a partir de reservatórios crustais na geração destas rochas caracterizando-se por valores negativos de $\varepsilon_{\mathrm{Nd}}$ e positivos de $\boldsymbol{\varepsilon}_{\mathrm{Sr}}$. Exceção ocorre na amostra representativa do enclave diorítico (K-16D) que apresentou valor de $\boldsymbol{\varepsilon}_{\mathrm{Nd}}$ próximo a zero, sugerindo contribuição mantélica na sua formação.

Os protólitos paleoproterozóicos das rochas gnáissico- migmatíticas, preservados na região de Oliveira Barros (Foto 1), podem ter sido formados em um regime distensivo possivelmente do Riaciano médio. Este processo pode ter sido responsável pelo metamorfismo da facies granulito do Complexo Itatins, ocorrido próximo a 2,1 Ga (Picanço et al., 1998). Estas rochas, originadas a partir deste evento distensivo, foram posteriormente deformadas e migmatizadas no Neoproterozóico III.

A influência neoproterozóica também pode ser observada na estruturação destas rochas, que apresentam uma foliação milonítica associada ao Sistema de Cisalhamento Cubatão e Itariri superimposta ao bandamento gnáissico irregular presente. Localmente, pode ser observado o total estiramento dos enclaves máficos presentes nestas rochas.

As rochas que ocorrem na porção sudeste de São Paulo, a sul das ZCC e ZCI, já foram correlacionadas às rochas do Domínio Curitiba (Siga Jr., 1995) ou à Microplaca Curitiba, em trabalhos regionais (Campos Neto \& Figueiredo, 1995; Basei et al., 1999). A partir do trabalho realizado nesta área, são confirmadas as correlações entre o Domínio Curitiba e o denominado Domínio Registro, com a associação entre as rochas granito-gnáissicas migmatíticas aflorantes a sul do SCCI e a norte da ZCS, com as rochas gnáissicas bandadas do Complexo Atuba (Siga Jr. et al., 1995) do Domínio Curitiba.

As rochas granito-gnáissicas migmatíticas do Complexo Atuba e do Domínio Registro apresentam idades U-Pb (zircões) entre 1,9 e 2,2 Ga, com evidências de retrabalhamento neoproterozóico. No entanto, o evento brasiliano pode ter sido muito mais intenso na região SE do estado de SP do que o observado no Complexo Atuba, onde o registro paleoproterozóico é mais preservado, como pode ser observado nas datações U-Pb em zircão (Siga Jr., 1995; Siga Jr. et al. 1995). Ambos domínios mostram idades TDM entre 2,8 e 2,7 Ga e localmente 2,4 Ga (Gnaisses Serra de Timirim no Domínio Registro e Gnaisses Mandirituba no Complexo Atuba).

As rochas granito-gnáissicas do Domínio Registro tendem a apresentar razões $\left(\mathrm{Sr}^{87} / \mathrm{Sr}^{86}\right)$ i mais elevadas, entre 0,716 e 0,723 , que as razões observadas nas rochas gnáissicas do Complexo Atuba, entre 0,713 e 0,716 (Siga Jr. etal., 1995).

\section{DOMÍNIO MONGAGUÁ}

O Domínio Mongaguá foi definido entre a Zona de Cisalhamento Cubatão (ZCC) e Zona de Cisalhamento Itariri (ZCI) (Figura 2), onde foram identificadas rochas gnáissicomigmatíticas (afloramentos-tipo na região de Mongaguá e Itanhaém) e rochas granitóides, estas subdivididas em três grupos principais: Tipo Itariri (monzogranitos, granodioritos e tonalitos, localmente com feições gnáissico-migmatíticas), Tipo Areado (monzogranitos e localmente tonalitos) e Ri- 

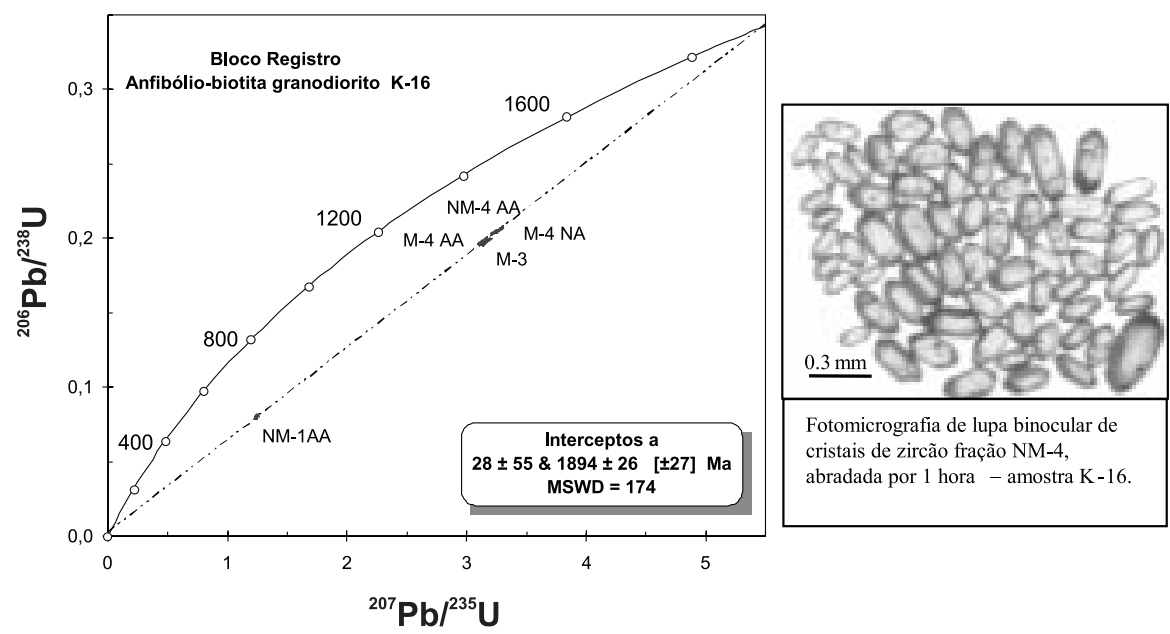

Figura 4. Diagrama Concórdia ${ }^{207} \mathrm{~Pb} /{ }^{235} \mathrm{U} \times{ }^{206} \mathrm{~Pb} /{ }^{238} \mathrm{U}$ em zircões - amostra K-16 (O liveira Barros).

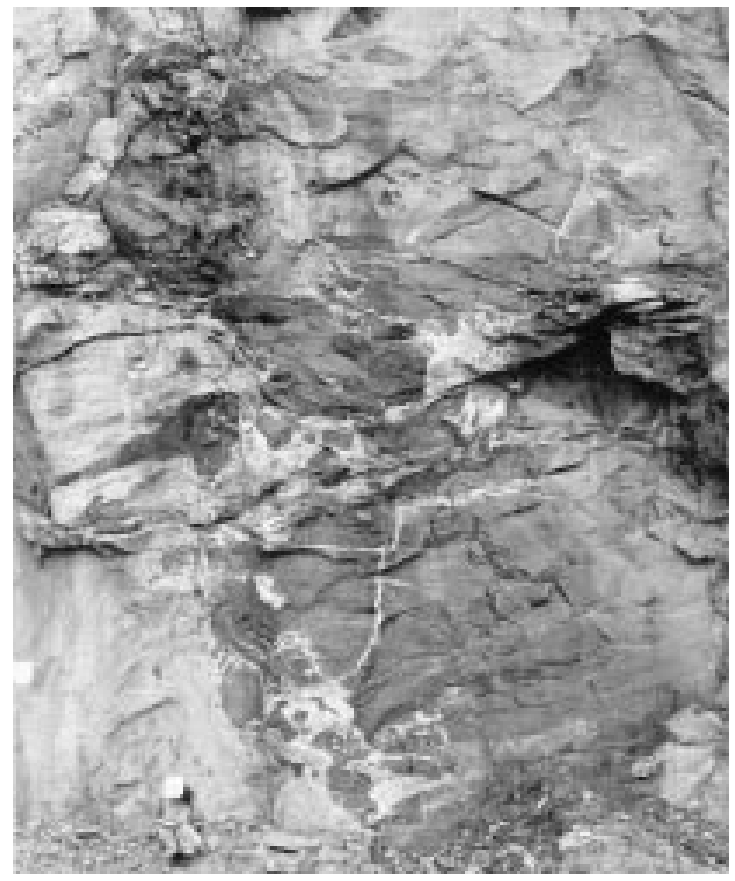

Foto 1. Dique diorítico sin-intrusivo em material granodiorítico. Região próxima a O liveira Barros Rodovia BR-116. Afloramento K-16. (D. Registro).

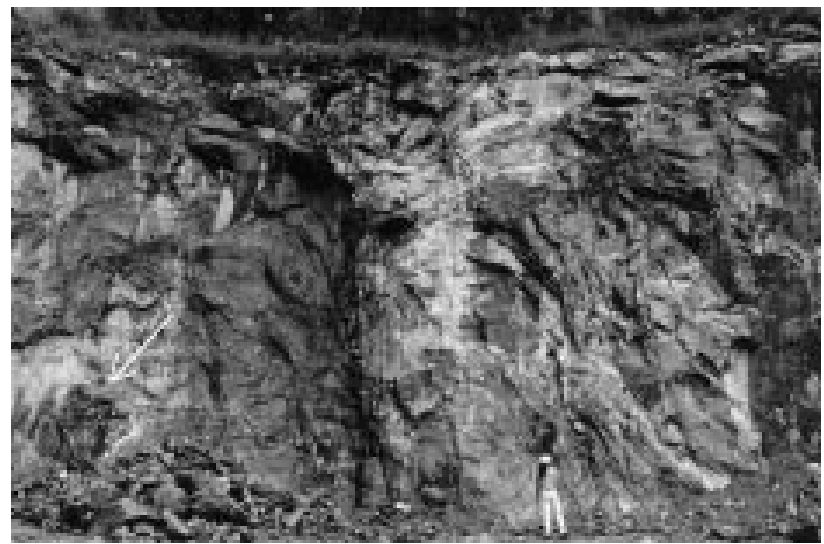

Foto 2. Magma mixing entre material granítico e diorítico com enclaves parcialmente assimilados (seta). Proximidades de Oliveira Barros. Afloramento K-17. (D. Registro).

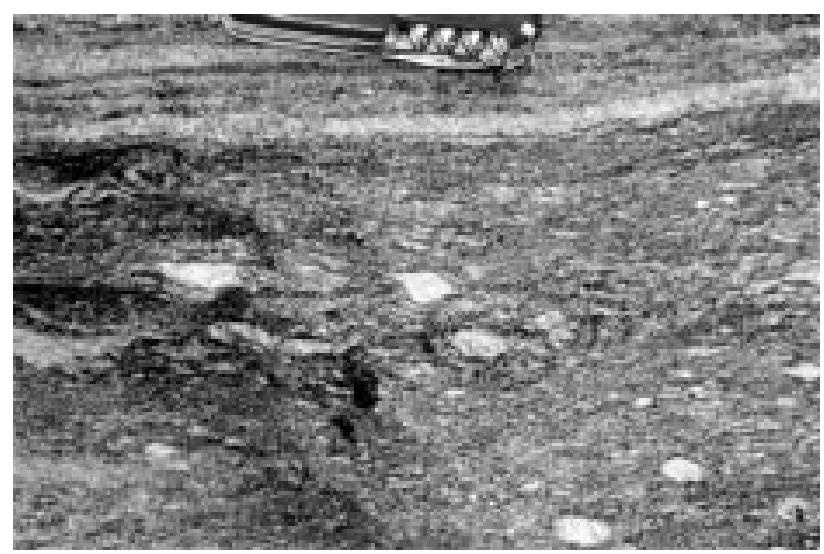

Foto 3. Paragnaisse com foliação milonítica definida por bandas quarto-feldspáticas e orientação e estiramento de porfiroclastos centimétricos de feldspato e granada. Maciço da Juréia (D. Registro). 


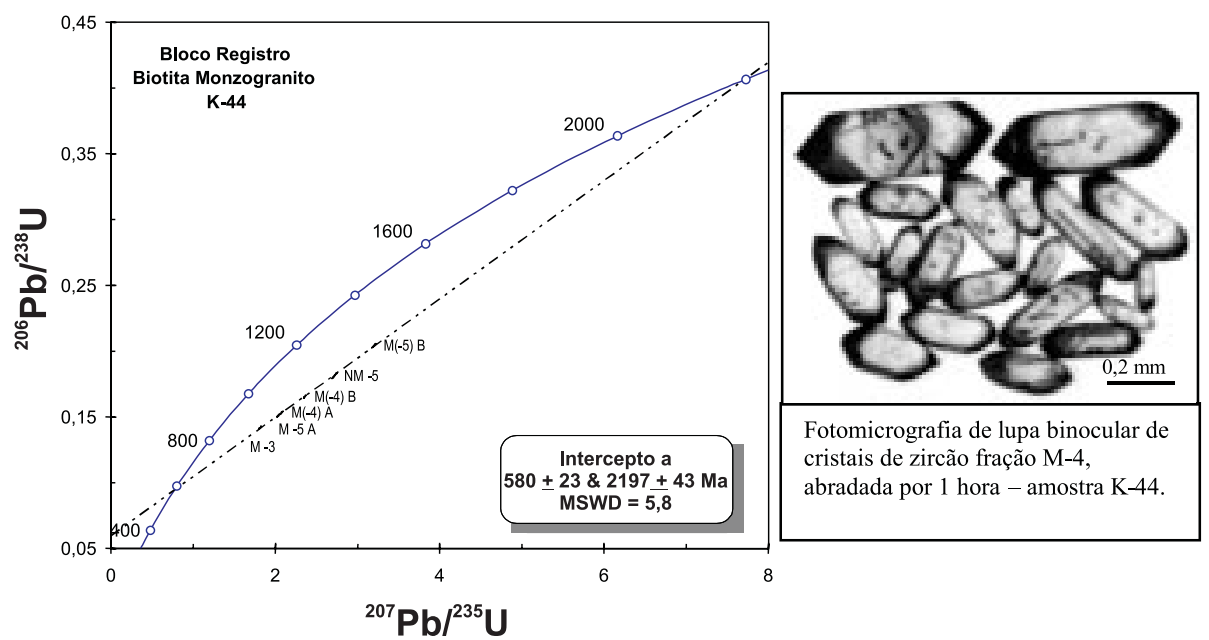

Figura 5. Diagrama Concórdia ${ }^{207} \mathrm{~Pb} /{ }^{235} \mathrm{U} \times{ }^{206} \mathrm{~Pb} /{ }^{238} \mathrm{U}$ em zircões - amostra K-44 (Serra Timirim).

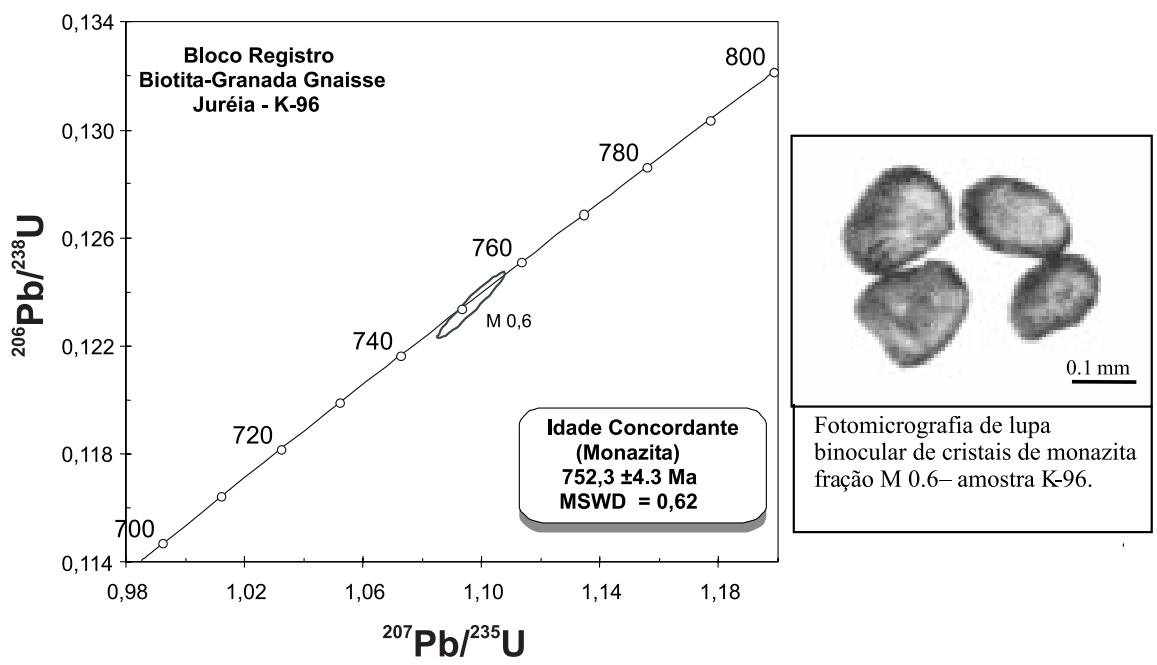

Figura 6. Diagrama Concórdia ${ }^{207} \mathrm{~Pb} /{ }^{235} \mathrm{U} \times{ }^{206} \mathrm{~Pb} /{ }^{238} \mathrm{U}$ em monazitas - amostra K-96 (Juréia).

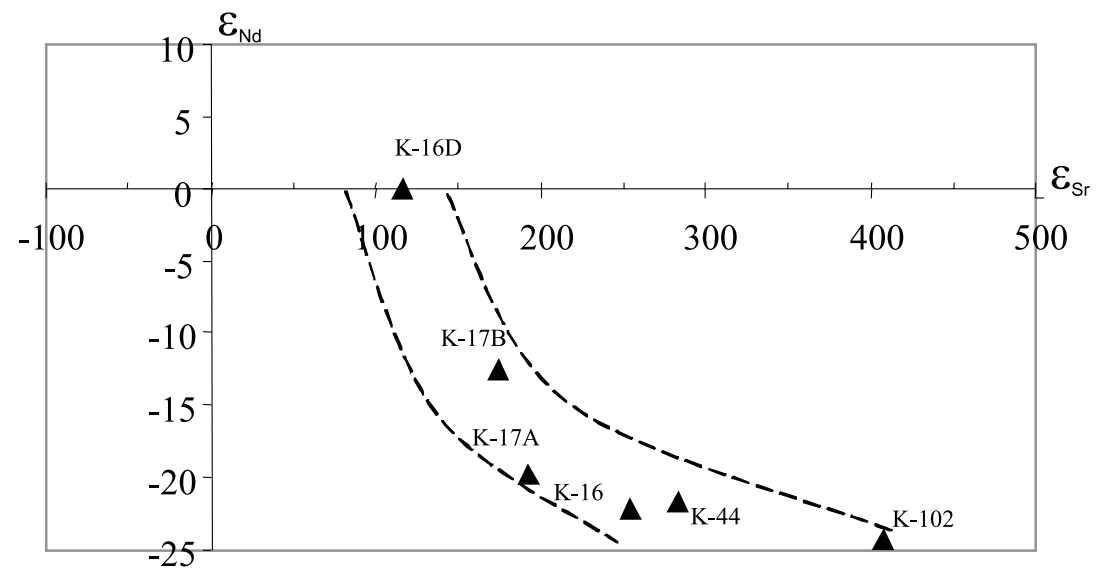

Figura 7. Diagrama de evolução $\varepsilon_{\mathrm{Nd}} x$ tempo (Ga) (D. Registro). 
beirão do Óleo (predominantemente monzogranitos), definidos por Passarelli, (2001).

Este Domínio corresponde aos migmatitos indiferenciados do Complexo Costeiro (Gimenez Filho et al., 1987), aos terrenos gnáissico-migmatíticos da Microplaca Serra do Mar (Campos Neto \& Figueiredo, 1995; Campos Neto, 2000) e ao Cinturão Granítico Costeiro (Basei et al., 1999, 2000), correlacionado por estes autores ao Batólito Paranaguá (Basei et al., 1990).

Na região de Mongaguá e Itanhaém, feições texturais observadas, como a presença de enclaves máficos microgranulares, contato irregular em cúspide e fragmentos de diques sin-intrusivos, sugerem uma íntima associação entre magmas distintos (mingling/mixing): um granítico (mais frio) e um básico (mais quente), na geração das rochas gnáissico-migmatíticas (Foto 4). A coexistência de magmas que podem ter se cristalizado concomitantemente, permitiu a formação de rochas híbridas, que foram intensamente deformadas (gnaisses bandados). A ocorrência de granitos híbridos, com presença de enclaves microgranulares, possivelmente está associada à origem profunda destas rochas.

A geração e colocação das rochas do Domínio Mongaguá possivelmente associadas a regimes compressivos podem ser corroboradas pelas feições estruturais observadas, como megaboudins na região de Itanhaém, indicativos de compressão EW, como também a observação de fluxo magmático condicionado a ambiente de achatamento aparente (elipsóides oblatos obtidos em granitóide não deformado). A deformação impressa nestas rochas possivelmente está relacionada ao momento de sua colocação e pode estar diretamente associada à justaposição do Domínio Mongaguá aos demais domínios tectônicos.

$\mathrm{Na}$ região de Mongaguá, em hornblenda-biotita monzogranítico com bandamento gnáissico incipiente e irregular, obteve-se uma idade concordante U-Pb em zircões de $612 \pm 3 \mathrm{Ma}$, interpretada como época mais provável para cristalização destas rochas (Figura 8, Tabela 1).

No Granito Ribeirão do Óleo, a NNE de Itariri, onde o magma mingling é bem caracterizado (Foto 5), a metodologia $\mathrm{U}-\mathrm{Pb}$ foi aplicada no material félsico (biotita monzogranito). As frações de zircão apresentaram forte herança isotópica, mostrando idades do intercepto inferior e superior extremamente imprecisas, havendo necessidade de refinamento da metodologia para estas rochas (Figura 9). A fração M(-4), relativamente mais concordante que as demais, apresentou uma idade ${ }^{206} \mathrm{~Pb} /{ }^{238} \mathrm{U}$ de $599 \mathrm{Ma}$, interpretada como a melhor estimativa da época de cristalização da rocha.

Nos Granitos Tipo Itariri predominam biotita monzogranitos foliados fracamente peraluminosos a peraluminosos, localmente apresentando feições gnáissicomigmatíticas.
Em biotita-monzogranito foliado, a norte da cidade de Itariri, e em biotita-tonalito protomilonítico, a norte de Peruíbe, as frações de zircão analisadas (Tabela 1) mostramse muito discordantes em Diagrama Concórdia indicando forte herança isotópica. Forneceram idades intercepto inferior de $578 \pm 12 \mathrm{Ma}$ e $647 \pm 8 \mathrm{Ma}$, respectivamente, interpretada com ressalvas, como a idade de formação destas rochas. $\mathrm{O}$ intercepto superior ofereceu idades imprecisas de $2137 \pm 100$ Ma e 1972 + 200/-170 Ma (Figura 10).

Os Granitos Tipo Areado, compostos de monzogranitos a granodioritos, mostram localmente feições gnáissicas e são correlacionados ao Granito Caepupu (Silva et al., 1978), ou "Granitos geralmente embrechíticos" (Silva, 1981; e Batolla Jr. et al., 1981), e ao Granito Ribeirão Braço Grande (Janasi \& Ulbrich, 1992). Até o momento, inexistem datações $\mathrm{U}-\mathrm{Pb}$ nestes granitos.

Característica comum aos Granitos Tipo Itariri e Ribeirão do Óleo é a herança isotópica paleoproterozóica, observada nas análises $\mathrm{U}-\mathrm{Pb}$ em zircões, obtendo-se idades intercepto inferior que devem ser interpretadas com ressalvas. Desse modo, se faz necessário uma diversificação da metodologia utilizada para datação destas rochas. No entanto, a idade em torno de 580 Ma pode ser considerada como importante fase magmática deste domínio, com a geração de rochas graníticas (Tipo Areado e Ribeirão do Óleo).

Neste contexto, os granitos Tipo Itariri, podem representar um magmatismo um pouco mais antigo, em relação aos granitos Areado e Ribeirão do Óleo.

As porções graníticas e dioríticas de Mongaguá e Itanhaém apresentam idades modelo TDM muito próximas (entre 1,7 e 1,8 Ga), bem como valores muito próximos de $\varepsilon_{\mathrm{Nd}}$ (Tabela 2). Tais idades indicam que os precursores dos materiais félsico e máfico das rochas aflorantes em Mongaguá, e da porção máfica de Itanhaém se diferenciaram do manto em épocas paleoproterozóicas próximas. Entretanto, por tratarem-se de rochas híbridas, fenômenos de mistura de diferentes fontes podem estar envolvidos na sua geração e tais resultados podem representar uma homogeneização isotópica.

$\mathrm{O}$ mesmo ocorre em relação aos isótopos de $\mathrm{Sr}$ (Tabela 3), onde as razões iniciais $\left(\mathrm{Sr}^{87} / \mathrm{Sr}^{86}\right) \mathrm{i}_{(600 \mathrm{Ma})}$ de 0,708 para ambos os materiais, também podem indicar a homogeneização isotópica ocorrida por mistura de magmas. No entanto, também sugerem, a influência de reservatórios crustais na origem destas rochas.

Os dados isotópicos de $\mathrm{Nd}$ e $\mathrm{Sr}$ (Tabelas 2 e 3) obtidos nos litotipos graníticos do Domínio Mongaguá indicam que os protólitos das rochas gnáissico-migmatíticas, dos Granitos Tipo Areado e Ribeirão do Óleo se diferenciaram do manto em épocas paleoproterozóicas próximas (entre 1,68 e $1,73 \mathrm{Ga})$ distintas dos Granitos Tipo Itariri (2,2 Ga). As razões isotópicas de $\mathrm{Sr}$ mostram valores de $\mathrm{Sr}^{87} / \mathrm{Sr}^{86}$ 


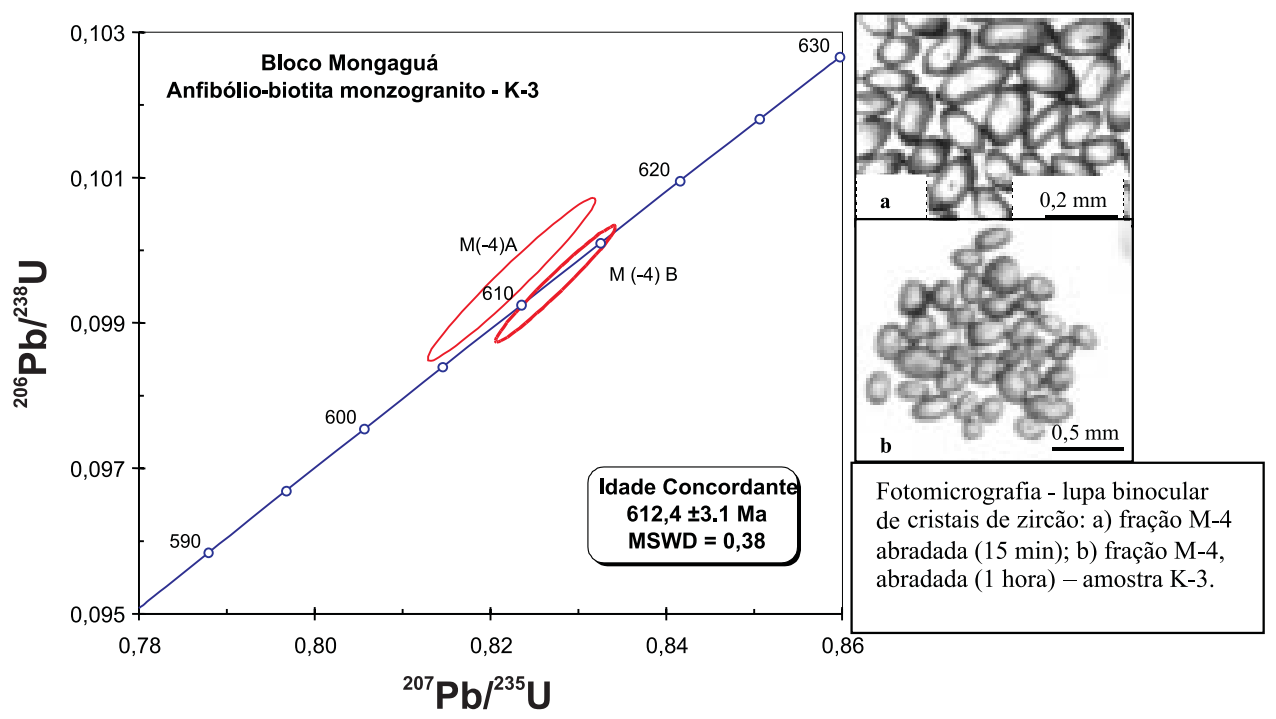

Figura 8. Diagrama Concórdia ${ }^{207} \mathrm{~Pb} /{ }^{235} \mathrm{U} \times{ }^{206} \mathrm{~Pb} / 238 \mathrm{U}$ em zircões da amostra K-3 (D. Mongaguá).

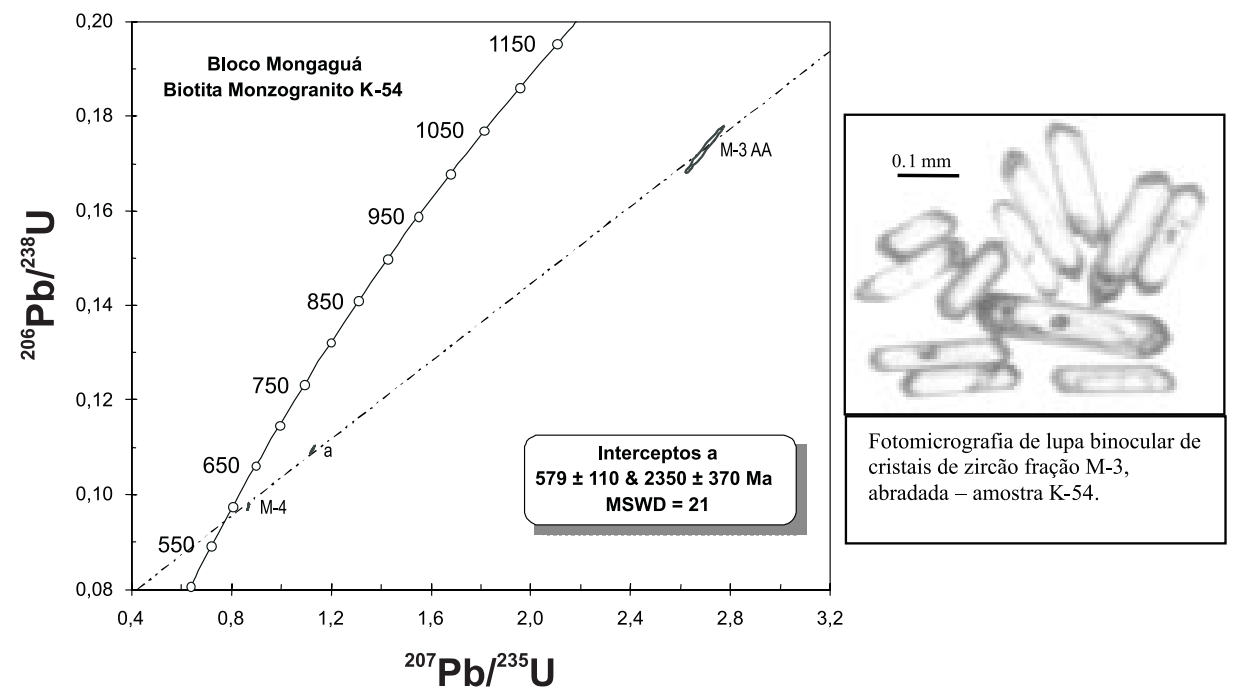

Figura 9. Diagrama Concórdia ${ }^{207} \mathrm{~Pb} /{ }^{235} \mathrm{U} \times{ }^{206} \mathrm{~Pb} /{ }^{238} \mathrm{U}$ em zircões da amostra K-54 (Granito Ribeirão do Óleo).

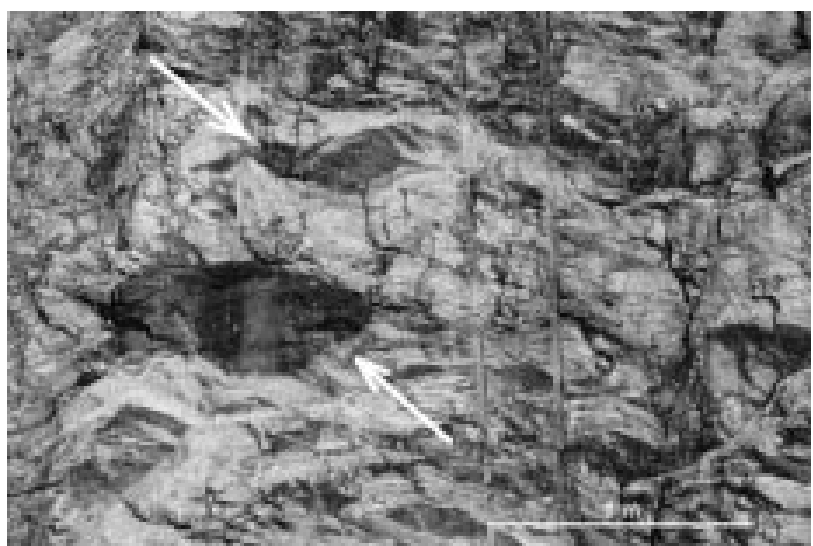

Foto 4. Enclaves máficos ovalados e sigmoidais (setas). Rochas gnáissicomigmatíticas. Afloramento K-103. (D. Mongaguá). 


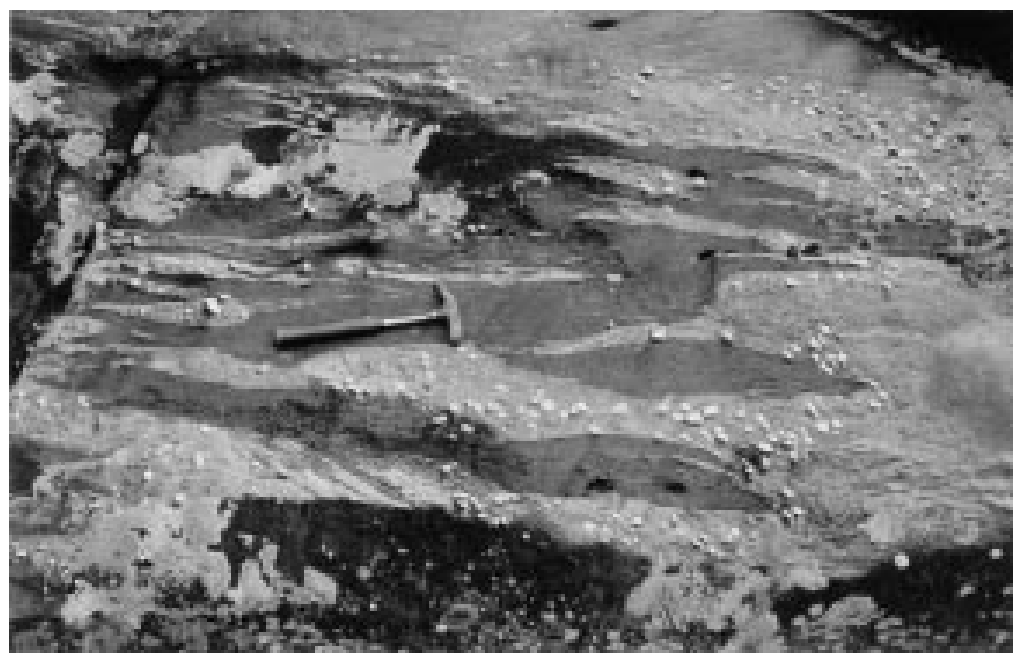

Foto 5. Magma mingling de material monzogranítico e máfico. Granito Ribeirão do Ó leo. Maior concentração de fenocristais de feldspato potássico próximo ao material máfico. Afloramento K-54. (D. Mongaguá).
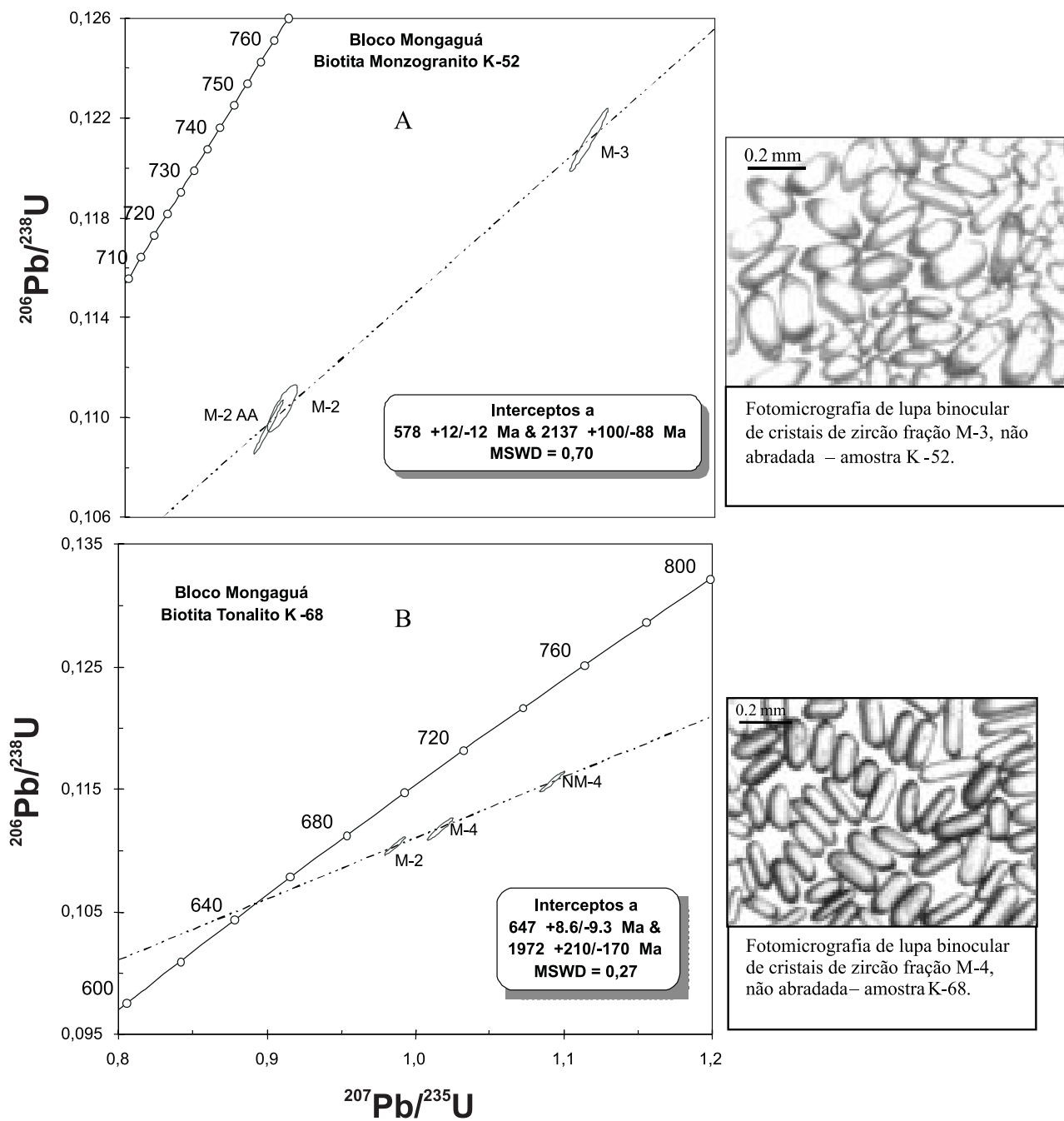

Figura 10. Diagrama Concórdia ${ }^{207} \mathrm{~Pb} /{ }^{235} \mathrm{U} \times{ }^{206} \mathrm{~Pb} /{ }^{238} \mathrm{U}$ em zircões (D. Mongaguá). A) Amostra K-52. B) Amostra K-68. Granitos Tipo Itariri. 
(i = 600 Ma) de 0,708 (Granito Ribeirão do Óleo), 0,714 (Granito Areado) e entre 0,711 a 0,724 (Granitos Tipo Itariri).

Em diagrama $\varepsilon_{\mathrm{Sr}} \times \varepsilon_{\mathrm{Nd}}(\mathrm{t}=600 \mathrm{Ma})$ nota-se um comportamento distinto entre as rochas gnáissicas de Mongaguá e Itanhaém e as rochas graníticas, e mesmo entre os diferentes tipos graníticos, comportamento indicativo de fontes distintas na geração destas rochas (Figura 11). Os valores negativos de $\varepsilon_{\mathrm{Nd}}$ e razões iniciais de $\mathrm{Sr}$ altas sugerem longo período de residência crustal e forte contribuição de fontes crustais na geração das rochas do Domínio Mongaguá, cujos protólitos se diferenciaram do manto em épocas paleoproterozóicas distintas. Essas fontes teriam características de reservatórios crustais, evidenciado pelo comportamento dos isótopos de $\mathrm{Nd}$ e $\mathrm{Sr}$ e pelas heranças observadas nos zircões.

O caráter cálcio-alcalino metaluminoso a fracamente peraluminoso das rochas gnáissico-migmatíticas e graníticas Tipo Itariri e a provável geração destas rochas associada a ambientes compressivos, sugerem que no Domínio Mongaguá estejam presentes rochas geradas em ambiente de arco magmático entre $640 \mathrm{Ma}$ (idade ainda imprecisa) e $610 \mathrm{Ma}$. Este período difere do obtido por Campos Neto \& Figueiredo (1995) para rochas de arco magmático associado à orogênese Rio Doce $(580$ - $565 \mathrm{Ma})$ na porção centronorte da Microplaca Serra do Mar e assemelha-se, em parte, ao período associado ao desenvolvimento do arco magmático Rio Negro pertencente ao Terreno Oriental (Heilbron et al., 1999), no Estado do Rio de Janeiro, com idades entre 640 a $600 \mathrm{Ma}$ (Tupinambá et al., 2000).

\section{DOMÍNIO IGUAPE}

O Domínio Iguape é composto por rochas graníticas e metassedimentares, balizado a norte pela Zona de
Cisalhamento Serrinha (ZCS) e a sul-sudeste pelo Oceano Attântico (Figura 2). Esta região é correlacionada ao Batólito Paranaguá (Basei et al., 1990) e associada ao Cinturão Granítico Costeiro (Basei et al., 1999, 2000). AZCS, que faz o contato entre os domínios Iguape e Registro, apresenta movimentação dextral com importante componente de cisalhamento puro (Passarelli, 2001).

As rochas estudadas do Domínio Iguape, referentes ao Maciço de Iguape, são correlacionadas aos granitóides pertencentes ao Domínio Paranaguá, cujos dados geocronológicos foram obtidos por Siga Jr. (1995).

Compreende rochas metassedimentares de baixo grau metamórfico e dois grupos de rochas graníticas. Um constituído por granitos que sustentam o Maciço de Iguape, normalmente protomiloníticos, e outro constituído por granitos semelhantes à Suíte Granítica Serra do Mar (Kaul \& Cordani, 1994).

As rochas metassedimentares caracterizam-se pela intercalação de metarenitos finos, homogêneos, com metassiltitos definindo um bandamento rítmico. Informalmente denominadas de Metassedimentos Iguape (Passarelli, 2001), assemelham-se às rochas aflorantes no setor setentrional da Ilha do Cardoso (Weber, 1998), podendo ser correlacionadas aos metassedimentos Rio das Cobras (Lopes, 1987). Apresentam uma foliação principal de direção em torno de EW/subvertical, paralela ao bandamento composicional.

Os granitos do Maciço do Iguape são peraluminosos e apresentam características similares aos granitos do tipo arco-vulcânico ou sin-colisionais (Passarelli, 2001). Na região de Iguape estes granitos são afetados por falhamento de movimentação dextral com componente normal, desenvolvendo textura protomilonítica (Foto 6).

Em biotita-monzogranito, localizado a nordeste de Iguape,

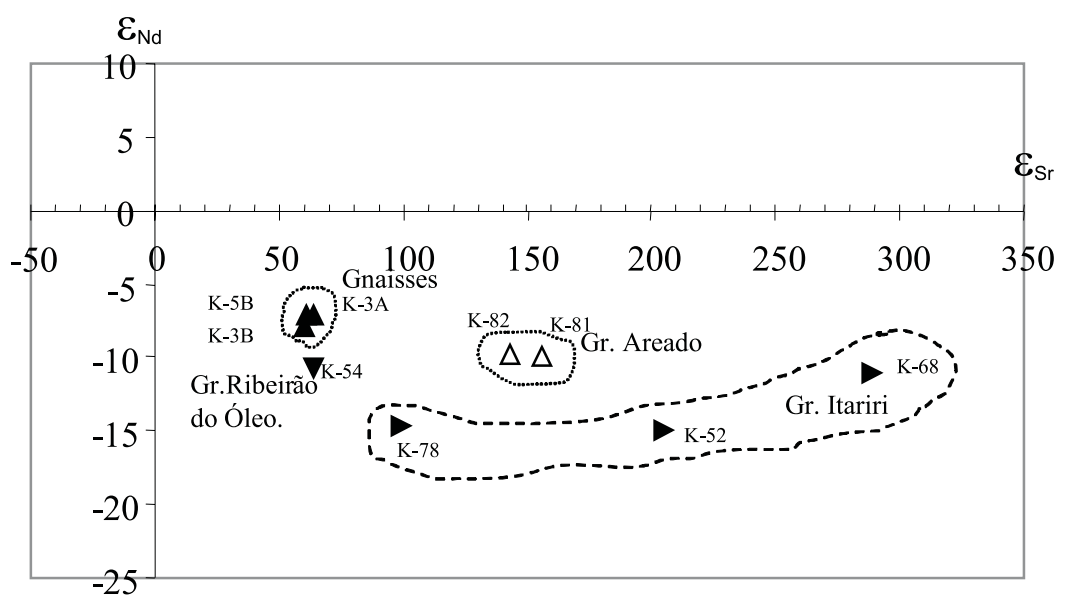

Figura 11. Diagrama $\varepsilon_{\mathrm{sr}} \times \varepsilon_{\mathrm{Nd}}(\mathrm{t}=600 \mathrm{Ma}$ ) (D. Mongaguá). 
no Morro do Espia, obteve-se uma idade U-Pb (zircões), intercepto superior de $599 \pm 15 \mathrm{Ma}$, interpretada como época de cristalização desta rocha (Tabela 1, Figura 12). Tal idade é semelhante aos valores obtidos nos granitóides tipo Morro Inglês e Rio do Poço do Domínio Paranaguá (Siga Jr., 1995).

As rochas graníticas do Domínio Iguape apresentaram dois períodos principais de diferenciação de seus protólitos do manto: idades modelo TDM em torno de 1,8 Ga (granitos do Morro do Espia), e em torno 2,2 Ga (granitos a NE de Iguape). Apresentaram valores de $\varepsilon_{\mathrm{Nd}}$ bastante próximos (Tabela 2), que sugerem a contribuição a partir de fontes crustais com características não muito distintas, na geração destes corpos. Razões $\left(\mathrm{Sr}^{87} / \mathrm{Sr}^{86}\right)$ i entre 0,711 e 0,714 (Tabela 3) corroboram esta hipótese. Em diagrama $\boldsymbol{\varepsilon}_{\mathrm{Sr}}$ x $\boldsymbol{\varepsilon}_{\mathrm{Nd}}$ (Figura 13) os litotipos analisados plotam próximos no quadrante inferior direito, indicativo, para geração destas rochas, de fontes similares com características de reservatórios crustais.

Os biotita-monzogranitos a megacristais que ocorrem no Maciço de Iguape, normalmente protomiloníticos são correlacionados aos granitos do Domínio Paranaguá (Siga Jr., 1995), e apresentam heranças isotópicas em zircões e idades TDM bastante variáveis, como observado nos Granitóides Tipo Morro Inglês (entre 1,9 e 2,2 Ga), Siga Jr., (op. cit.). Por outro lado, os granitos que ocorrem no Domínio Iguape, apresentam $\left(\mathrm{Sr}^{87} / \mathrm{Sr}^{86}\right)$ i sistematicamente mais elevadas (Tabela 3) que as observadas no Domínio Paranaguá (entre 0,707 e 0,708).

\section{SUÍTE INTRUSIVA SERRA DO MAR}

Rochas graníticas semelhantes à Suíte Intrusiva Serra do Mar ocorrem nos domínios Registro (Granito Votupoca) e Iguape (Serras do Paratiú, Cordeiro e Itapitangui). As rochas graníticas aflorantes na Serra do Paratiú já foram correlacionadas por Kaul \& Cordani (1994) à Suíte Granítica Intrusiva Serra do Mar, bem como o Granito Votupoca, intrusivo nas rochas gnáissico-migmatíticas do Domínio Registro, correlacionado a esta suíte por Vasconcellos et al. (1999). O Granito da Serra de Itapitangui, ou Granito Mandira, pode ser correlacionado à Unidade Mandira 1, definida por Oliveira (1989). Representam um magmatismo peraluminoso a metaluminoso, com tendência peralcalina, e assinatura de ambiente intraplaca (Passarelli, 2001).

Os granitos da Serra de Paratiú/Cordeiro e Itapitangui, aflorantes no Domínio Iguape, são metaluminosos, este último com tendência peralcalina.

No biotita-monzogranito isótropo da Serra do Cordeiro (Tabela 1) as frações de zircão analisadas pela metodologia $\mathrm{U}-\mathrm{Pb}$, principalmente as menos magnéticas apresentaram fortes heranças isotópicas (Figura 14). Frações menos dis- cordantes alinharam-se e forneceram uma idade intercepto superior de $582 \pm 4 \mathrm{Ma}$, interpretada como a época mais provável de cristalização desta rocha.

O biotita-monzogranito representativo do Granito Votupoca apresentou uma idade intercepto superior de $582 \pm 9 \mathrm{Ma}$, interpretada como época de cristalização desta rocha (Figura 15).

Valores de $\boldsymbol{\varepsilon}_{\mathrm{Nd}}$ negativos próximos (Tabela 2) e razão elevada $\left(\mathrm{Sr}^{87} / \mathrm{Sr}^{86}\right) \mathrm{i}=0,716$ (Tabela 3) indicam a contribuição a partir de fontes crustais com características similares na geração destes corpos graníticos.

Os Granitos Cordeiro e Votupoca apresentaram idades U-Pb (zircões) em torno de $580 \mathrm{Ma}$, e os Granitos da Suíte Serra do Mar entre 580 e 594 Ma (Siga Jr., 1995; Siga Jr. et al., 1999). Diferenças são observadas principalmente em relação às idades modelo TDM, sendo dos granitos intrusivos no Domínio Registro e Iguape mais antigas (entre 2,3 e 2,4 Ga, Tabela 2) que aquelas observadas na Suíte Granítica Serra do Mar, entre 1850 e 2100 Ma (Siga Jr., 1995).

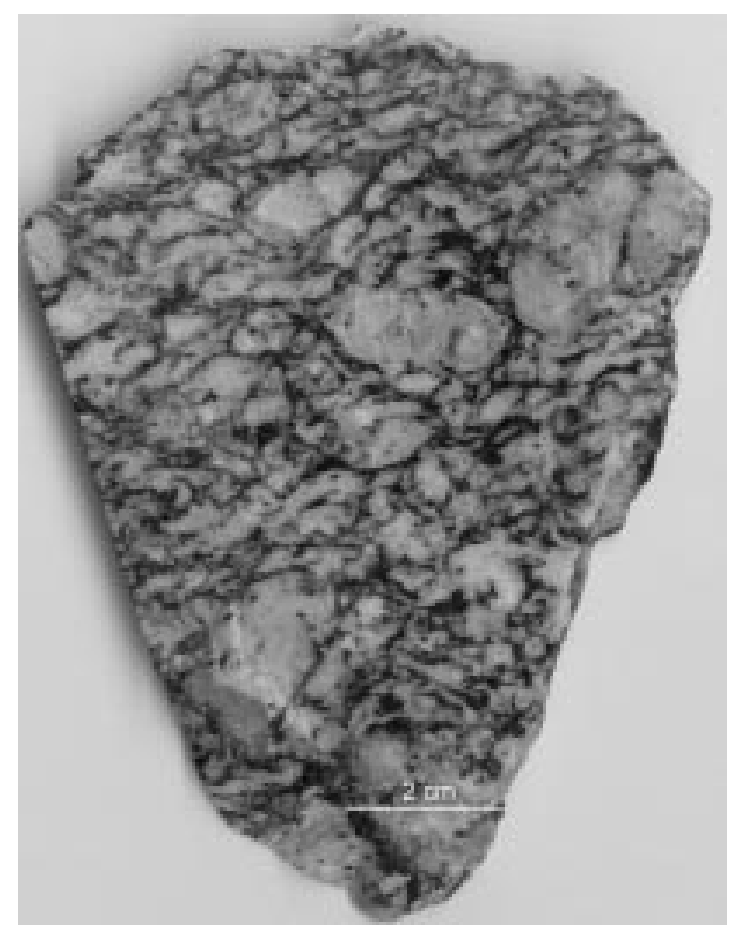

Foto 6. Protomilonito granítico (corte $X Z$ ). Porfiroclastos de feldspatos sugerem movimentação dextral. Morro do Espia. Afloramento K-100. (D. Iguape). 


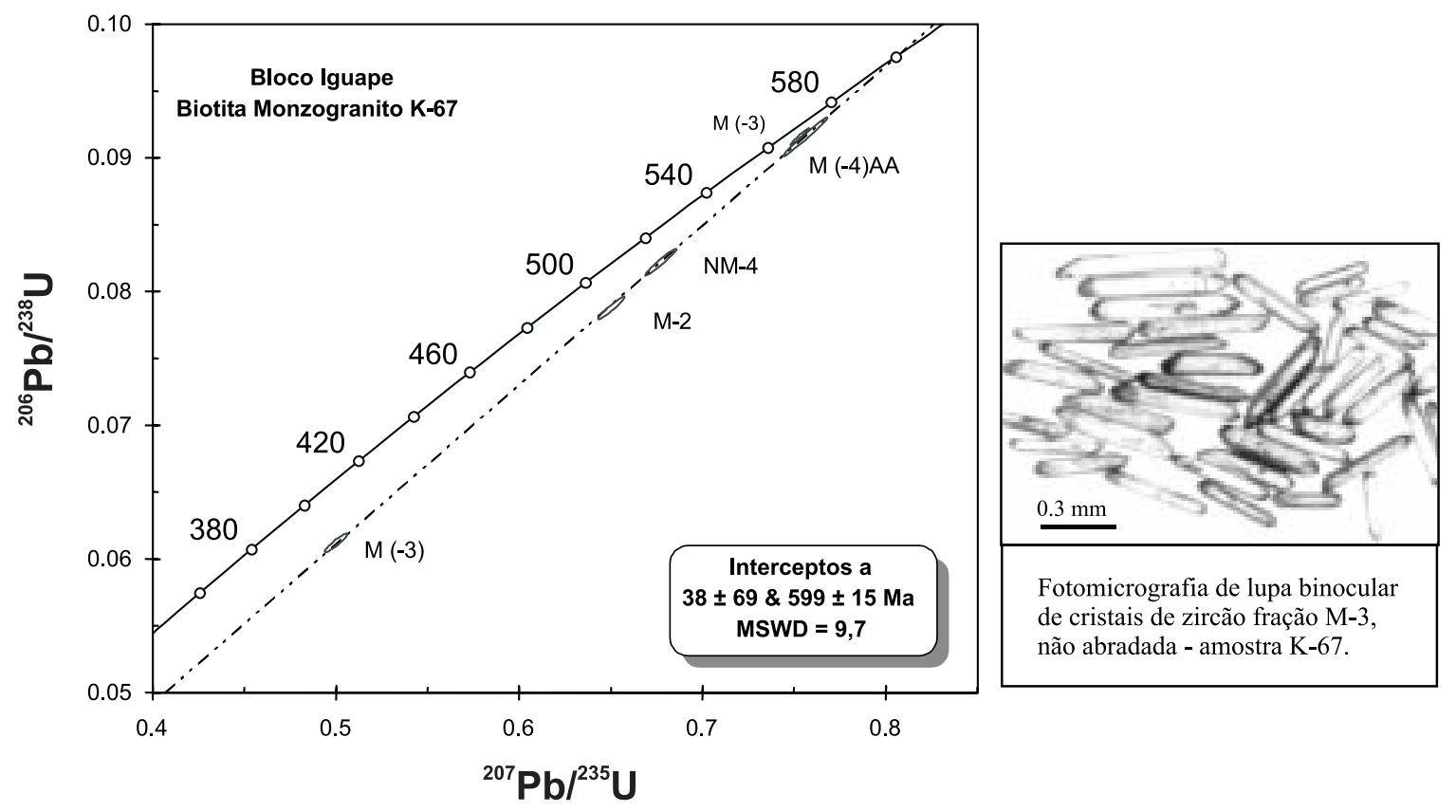

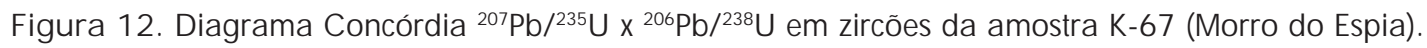

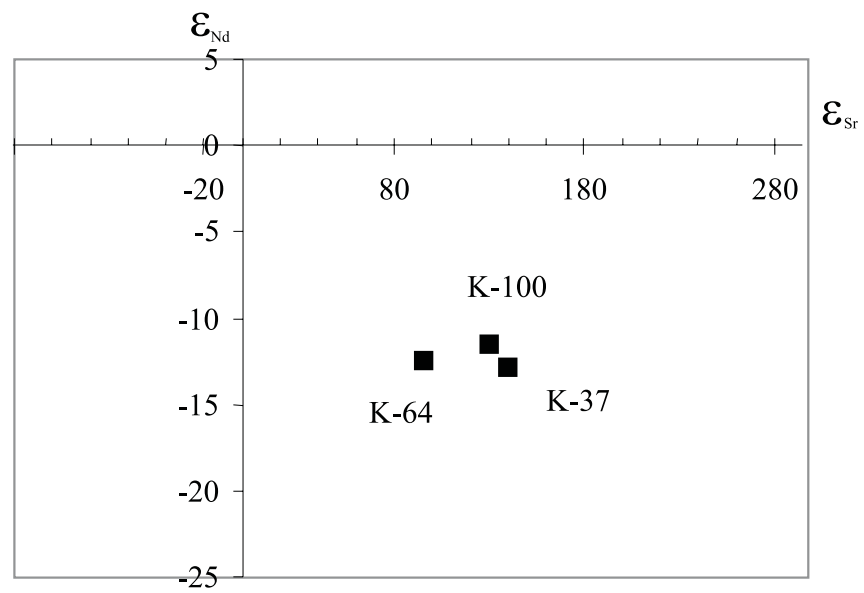

Figura 13. Diagrama $\varepsilon_{\mathrm{sr}} \times \varepsilon_{\mathrm{Nd}}(\mathrm{t}=600 \mathrm{Ma})$ - Rochas graníticas (D. Iguape). 


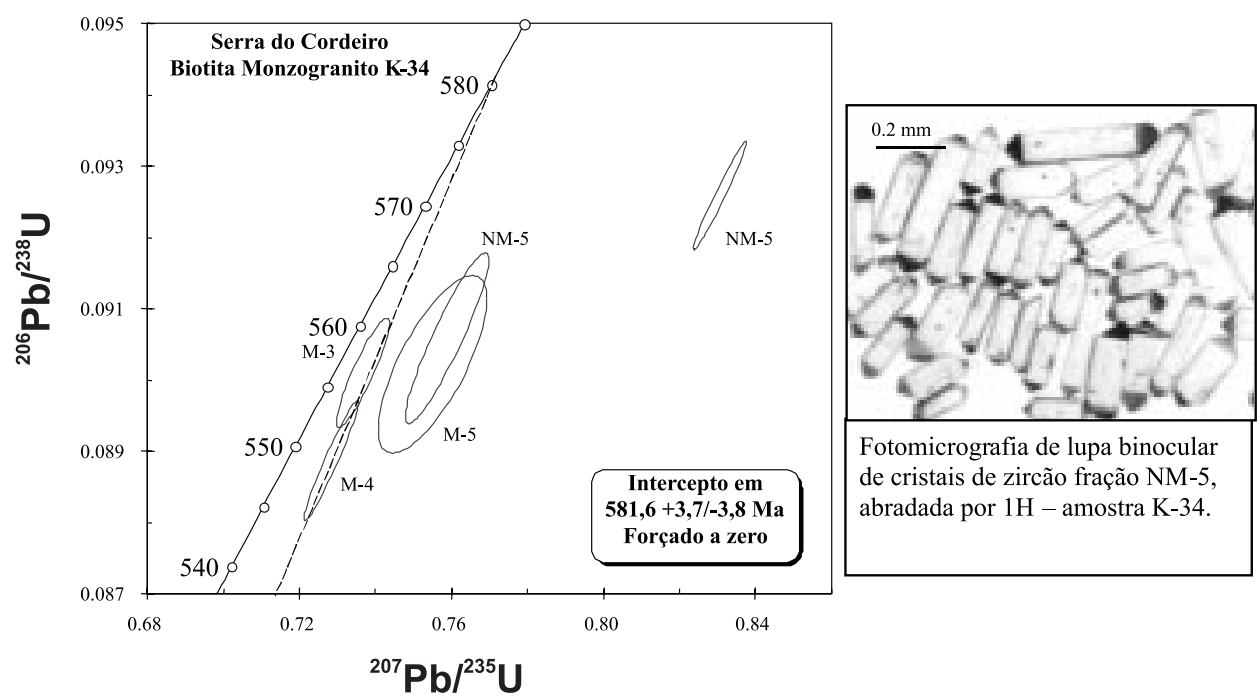

Figura 14. Diagrama Concórdia ${ }^{207} \mathrm{~Pb} /{ }^{235} \mathrm{U} \times{ }^{206} \mathrm{~Pb} /{ }^{238} \mathrm{U}$ em zircões da amostra K-34 (Serra do Cordeiro).

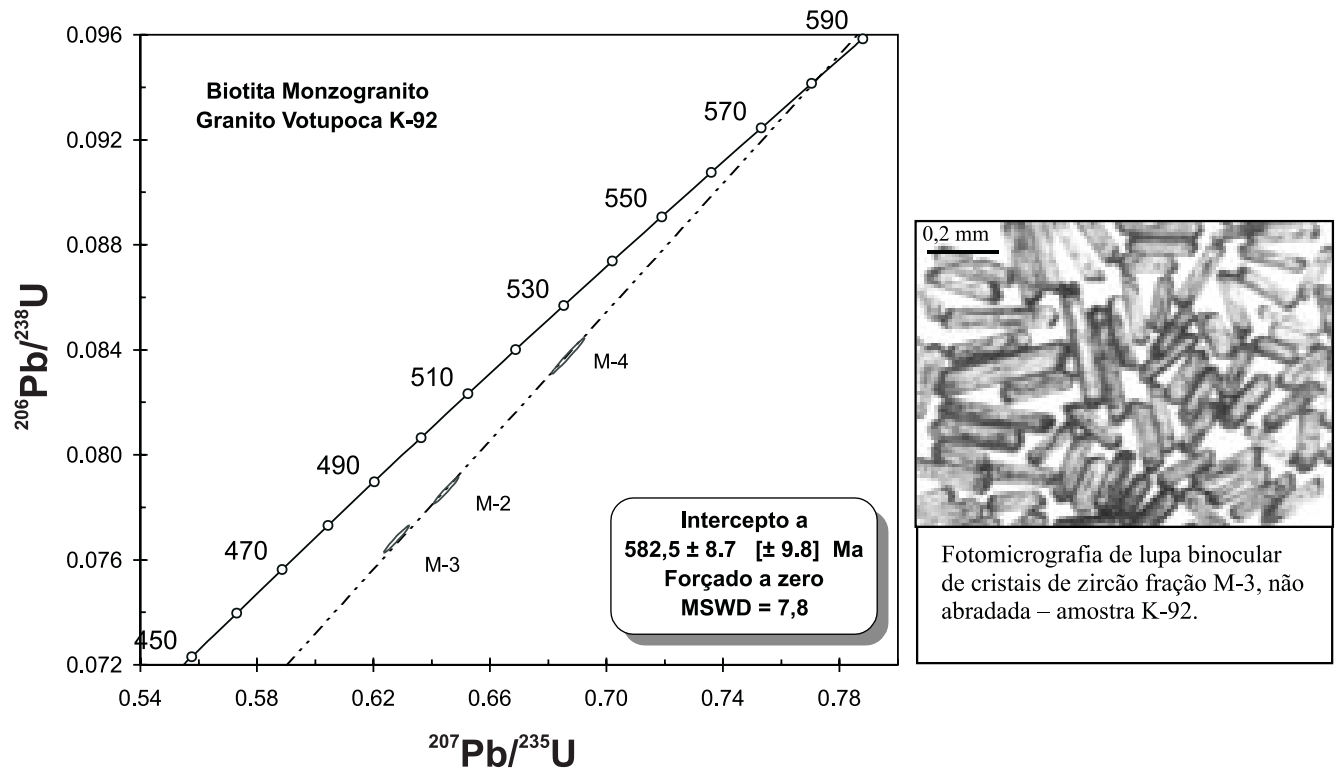

Figura 15. Diagrama Concórdia ${ }^{207} \mathrm{~Pb} /{ }^{235} \mathrm{U} \times{ }^{206} \mathrm{~Pb} /{ }^{238} \mathrm{U}$ em zircões da amostra K-92 (Serra do Votupoca). 


\section{CONSIDERAÇÕES FINAIS}

O quadro tectônico atual observado na porção sul-oriental do Estado de São Paulo, porção centro-sul do Cinturão Ribeira, estabeleceu-se no final do Neoproterozóico, como resultado de colagens associadas à formação do Gondwana Ocidental (Brito Neves et al., 1999; Almeida et al., 2000; Campos Neto, 2000), onde as rochas foram geradas e/ou afetadas de modo significativo pela tectônica brasiliana.

Os terrenos mais antigos na área, representados pelos domínios tectônicos Registro e Embu, apresentam evidências de evento térmico-metamórfico precoce, entre 800 e $750 \mathrm{Ma}$.

Possivelmente, a justaposição entre estes domínios tectônicos deve ter ocorrido em épocas neoproterozóicas muito próximas. Nesse contexto, o SCCI apresenta idade máxima de movimentação em torno de $596 \mathrm{Ma}$ (idade U-Pb em zircão obtida em gnaisse protomilonítico).

Granitos peraluminosos intrusivos no Domínio Embu, com cerca de 598 Ma encaixados em zonas de cisalhamento subparalelas ao SCCI, podem ter sua geração relacionada à compressão aproximadamente EW, que acarretou na justaposição do Domínio Mongaguá aos domínios Registro e Embu (Passarelli, 2001). Adicionalmente, corpos graníticos peraluminosos do Domínio Mongaguá, como os Granitos Areado e Ribeirão do Óleo, ambos com formas alongadas, podem também representar o magmatismo associado à justaposição deste domínio aos domínios adjacentes.

A geração das rochas graníticas Tipo Itariri e gnáissicomigmatíticas do Domínio Mongaguá (640 - 610 Ma) possivelmente associam-se a regimes compressivos, de arco magmático. A fase colisional, intrinsecamente associada à cinemática de justaposição do Domínio Mongaguá aos domínios Embu e Registro pode ter ocorrido entre 590 e $580 \mathrm{Ma}$, com a geração de granitos peraluminosos nos terrenos envolvidos. No Segmento Central da Faixa Ribeira extensivo magmatismo sin-colisional é reportado no período entre 600 e $560 \mathrm{Ma}$ (Heilbron et al., 1999).

A época mais provável da justaposição do Domínio Iguape ao Registro, entre 570 e 580 Ma é sugerida através de datações U-Pb em monazitas de protomilonito granítico da ZCS. Machado et al. (1996) sugerem que parte significativa da Faixa Ribeira Central, apresenta um pico metamórfico entre 560 e $580 \mathrm{Ma}$ (monazita e titanita). Idades U-Pb em titanitas nos batólitos Graníticos Cunhaporanga e Três Córregos com pico em torno de $560 \mathrm{Ma}$, são interpretadas por Prazeres Filho (2000) como importante evento termal que afetou a Faixa Ribeira Sul.

Idades em torno de $500 \mathrm{Ma}$ obtidas por datações K-Ar (biotita) em rochas miloníticas do SCCI, da ZCS, de faixa milonítica interna ao Domínio Registro e em granito isótropo da Serra do Cordeiro (Domínio Iguape) devem representar a época de resfriamento dos domínios tectônicos envolvidos.

\section{REFERÊNCIAS BIBLIOGRÁFICAS}

ALMEIDA, F. F.M.; HASUI, Y.; BRITO NEVES, B. B.;FUCK, R. A. Brazilian structural provinces: an introduction. Earth Science Reviews, v. 17, p. 1-29, 1981.

ALMEIDA, F. F. M.; BRITO NEVES, B. B.; CARNEIRO, C. D. R. The origin and evolution of the South American Plataform. Earth Science Reviews, v. 50, p. 77-111, 2000.

AZEVEDO SOBRINHO, J. M. Petrologia dos Charnockitos da Região de Itariri (SP). 1995. 112 f. Dissertação (Mestrado) - Instituto de Geociências, São Paulo.

BASEI, M. A. S.; SIGA JÚNIOR., O.; REIS NETO, J. M. O Batólito Paranaguá. Proposição, idade, considerações petrogenéticas e implicações tectônicas. In: CONGRESSO BRASILEIRO DE GEOLOGIA, 36., 1990. Natal. Anais...Natal: SBG, v. 4, p.1684-1699.

BASEI, M. A. S.; SIGA JÚNIOR., O.; REIS NETO, J. M.; PASSARELLI, C. R.; PRAZERES, H. J.; KAULFUSS, G.; SATO, K.; LIMA, P. S. Paleoproterozoic granulitic belts of the Brazilian Southern Region (PR-SC). In: SOUTHAMERICAN SYMPOSIUMON ISOTOPEGEOLOGY, 2. 1999. Córdoba. Extended Abstracts. Córdoba: SEGEMAR, 1999. p. 291-294.

BASEI, M. A. S.; SIGA JÚNIOR, O.; MASQUELIN, H.; HARARA, O. M.; REIS NETO, J. M.; PRECIOZZI, P. The Dom Feliciano Belt of Brazil and Uruguai and its foreland domain, the Rio de La Plata Craton: framework, tectonic evolution and correlation with similar provinces of southwestern Africa. In: CORDANI, U. G.; MILANI, E. J.; THOMAS FILHO, A.; CAMPOS, D. A. (Eds.) Tectonic Evolution of South America. Rio de Janeiro, 2000, p. 311-334.

BATTOLA JÚNIOR., F.; SILVA, A. T. S. F.; FRANCISCONI, O.; GODOY, A. M. Projeto Integração e Detalhe Geológico no Vale do Ribeira. São Paulo, 1981, v. 2-3. (Relatório Final).

BRITO NEVES, B. B.; CAMPO NETO, M. C.; FUCK, R. A. From Rodinia to Western Gondwana: An approach to the Brasiliano-Pan African Cycle and orogenic collage. Episodes, v. 22, p. 155-166, 1999.

CAMPOS NETO, M. C. Orogenic Systems from Southwestern Gondwana: an approach to Brasiliano-Pan African cycle and orogenic collage in southeastern Brazil. In: CORDANI, U. G.; MILANI, E. J.; THOMAS FILHO, A.; CAMPOS, D. A. (Eds.) Tectonic Evolution of South America. Rio de Janeiro: s.n. 2000. p. 335-365.

CAMPOS NETO, M. C.; FIGUEIREDO, M. C. H. The Rio Doce Orogeny, southeastern Brazil. Journal of South American Earth Sciences, v. 8, n. 2, p. 143-162, 1995.

CORDANI, U. G.; COUTINHO, J. M. V.; NUTMAN, A. 
Geochronological constraints for the age of the Embu Complex, São Paulo, Brazil. In: INTERNATIONAL GEOLOGICAL CONGRESS, 31., 2000. Rio de Janeiro. Abstracts Volume. Rio de Janeiro: CPRM, 2000. 1 CD-ROM.

DANTAS, A. S. L.; GIMENEZ FILHO, A.; TEIXEIRA, A. L.; NAGATA, N.; FERNANDES, L. A.; ALBUQUERQUE FILHO, J. L.; FRASCÁ, M. H. B. O. Evolução geológica e estrutural da faixa costeira nas regiões de Juquiá e Miracatu, Sul do Estado de São Paulo. In: SIMPÓSIO REGIONAL DE GEOLOGIA, 6., Rio Claro, 1987. Anais...Rio Claro: SBG. v.1, p. 173-189, 1987a.

DANTAS, A. S. L.; GIMENEZ FILHO, A.; TEIXEIRA, A. L.; NAGATA, N.; FERNANDES, L. A.; ALBUQUERQUE FILHO, J. L.; FRASCÁ, M. H. B. O. Geologia das folhas Juquiá (SC.23-V-A-I-4) e Miracatu (SG23-V-A-II-3), Estado de São Paulo. . São Paulo, IPT: 1987b.

FERNANDES, A J. O Complexo Embu no leste do estado de São Paulo: contribuição ao conhecimento da litoestratigrafia e da evolução estrutural e metamórfica. 1991. 120 f. Dissertação - (Mestrado) -Instituto de Geociências de São Paulo, Universidade de São Paulo, São Paulo.

GIMENEZ FILHO, A.; ALBUQUERQUE FILHO, J.L.; DANTAS, A. S. L. FERNANDES, L. A.; NAGATA, N.; TEIXEIRA, A. L. Geologia da Folha Miracatu, S-SE do estado de São Paulo. In: SIMPÓSIO REGIONAL DE GEOLOGIA, 6., 1987. Rio Claro. Anais... Rio Claro: SBG, 1987. v.1, p. 225-241.

HACKSPACHER, P. C.; DANTAS, E. L.; SPOLADORE, A.; FETTER, A. H.; OLIVEIRA, M. A. F. Evidence of Neoproterozoic Backarc Basin development in the Central Ribeira Belt, Southeastern Brazil: new geochronological and geochemical constraints from the São Roque - Açungui Groups. Revista Brasileira de Geociências, v. 30, n. 1, p. 110-114, 2000.

HASUI, Y.; DANTAS, A. S. L.; CARNEIRO, C. D. R.; BISTRICH, C. A. O embasamento Pré-Cambriano e EoPaleozóico em São Paulo. In: INSTITUTO DE PESQUISAS TECNOLÓGICAS DE SÃO PAULO. Mapa Geológico do Estado de São Paulo, escala 1.500.000. São Paulo: IPT, 1981. v.1, p.12-45. (Publicação, 1184).

HEILBRON, M.; VALERIANO, C.; TUPINAMBÁ, M.; ALMEIDA, J.; VALLADARES, C.; DUARTE, B.; PALERMO, N.; SILVA, L. G. E; RAGATKY, D.; NETTO, A. M. Revisão da proposta de compartimentação tectônica e modelo evolutivo para o segmento central da Faixa Ribeira. In: SIMPÓSIO GEOLOGIA SUDESTE, 6., 1999. São Pedro. Boletim de Resumos. São Pedro: SBG, 1999.p. 6.

JANASI, V. A. Petrogênese de granitos crustais na Nappe de Empurrão Socorro-Guaxupé (SP-MG): uma contri- buição da geoquímica elemental e isotópica. 1999. 304 f. Tese (Livre - Docência) - Instituto de Geociências, Universidade de São Paulo, São Paulo.

JANASI, V. A.; ULBRICH. H. H. G. J. Inventário bibliográfico de Granitos do Estado de São Paulo. Boletim IG-USP. Publicação Especial, no 11, p. 1- 253, 1992.

JANASI, V. A.; LEITE, R. J.; VAN SCHMUS, W. R. U-Pb chronostratigraphy of the granitic magmatism in the Agudos Graneds Batholith (west of São Paulo, Brazil) implications for the evolution of the Ribeira Belt. Journal of South American Earth Sciences, v.14, p. 376, 2001.

KAUL, P. F. T.; CORDANI, U. G. Aspectos petrográficos, geoquímicos e geocronológicos dos maciços graníticos da Serra do Mar no leste do Paraná e vizinhanças. In: CONGRESSO BRASILEIRO DE GEOLOGIA, 38., 1994. Camboriú. Boletim de Resumos Expandidos. Camboriú, SBG, 1994. v. 2, p.371-372.

LEITE, R. J. Petrogênese e geocronologia $U-P b$ do magmatismo granítico tardi a pós-orogênico no Batólito Agudos Grandes (SP). 2003. 218 f. Tese (Doutorado) - Instituto de Geociências, Universidade de São Paulo.

LOPES, O. F. Zoneamento metamórfico da Formação Rio das Cobras do pré-cambriano do estado do Paraná. In: SIMPÓSIO SUL-BRASILEIRODEGEOLOGIA, 3., 1987. Curitiba, Atas. Curitiba: SBG, 1987. v.1, p. 303-312.

MACHADO, N.; VALLADARES, C.; HEIBRON, M.; VALERIANO, C. U-Pb geochronology of Central Ribeira Belt (Brazil) and implication for the evolution of the Brazilian Orogeny. Precambrian Research, v. 79, p. 347-361, 1996.

OLIVEIRA, M. C. B. Petrologia do Maciço Granítico Mandira-SP. 1989. 178 f. Dissertação (Mestrado) - Instituto de Geociências, Universidade de São Paulo, São Paulo.

PASSARELLI, C. R. Caracterização estrutural e geocronológica dos domínios tectônicos da porção suloriental do Estado de São Paulo. 2001. 254 f. Tese (Doutorado) - Instituto de Geociências, Universidade de São Paulo, São Paulo.

PASSARELLI, C. R.; BASEI, M. A. S.; CAMPOS NETO, M. C.; SIGA JÚNIOR, O.; PRAZERES FILHO, H. J. Geology and $\mathrm{U}-\mathrm{Pb}$ geochronology of precambrian terranes of southeastern São Paulo State, Brazil. In: INTERNATIONALGEOLOGICALCONGRESS, 31., 2000. Rio de Janeiro. Abstracts Volume. Rio de Janeiro: CPRM, 2000. 1 CD-ROM.

PERUGINI, D.; POLI, G.; GATTA, G. D. Analysis and simulation of magma mixing processes in 3D. Lithos, v. 65, p. 313-330, 2002.

PICANÇO, J. L. Aplicação das sistemáticas $\mathrm{Sm} / \mathrm{Nd}$ e Rb/Sr no Maciço de Itatins (SP). 1994. 140 f. Dissertação 
(Mestrado) - Instituto de Geociências, Universidade de São Paulo, São Paulo.

PICANÇO J.; TASSINARI, C. C. G.; CORDANI, U. G.; NUTMAN, A. P. Idades U-Pb (SHRIMP), Sm-Nd e Rb-Sr em rochas do Maciço de Itatins (SP): Evidências de Evolução Policíclica. Anais da Academia Brasileira de Ciências, v. 70, n.1, p. 139-150, 1998.

PRAZERES FILHO, H. J. Litogeoquímica, Geocronologia $(U-P b)$ e Geologia isotópica dos Complexos Graníticos Cunhaporanga e Três Córregos, Estado do Paraná. 2000. 180 f. Dissertação (Mestrado) - Instituto de Geociências, Universidade de São Paulo, São Paulo.

SIGA JÚNIOR, O. Domínios tectônicos do sudeste do Paraná e nordeste de Santa Catarina. Geocronologia e evolução crustal. 1995. 212 f. Tese (Doutorado) - Instituto de Geociências, Universidade de São Paulo, São Paulo.

SIGA JÚNIOR, O.; BASEI, M. A. S.; REIS NETO, J. M.; MACHIAVELLI, A.; HARARA, O. M. OComplexo Atuba: um cinturão Paleoproterozóico intensamente retrabalhado no Neoproterozóico. Boletim - IG-USP, Série Científica, 26, p. 69-98, 1995.

SIGAJÚNIOR, O.; BASEI, M.A. S.; SATO, K.; CITRONI, S. B.; REIS NETO, J. M.; WEBER, W.; LIMA, P. S.; SPROESSER, W. M. Pos-Orogenic magmatism and sedimentation in Neoproterozoic extensional regimes in the Brazilian Southern Region. In: SOUTH-AMERICAN SYMPOSIUM ONISOTOPE GEOLOGY, 2., 1999. Córdoba. Extended Abstracts. Córdoba: SEGEMAR, 1999. p. 367-370.

SILVA, A. T. S. F. Tentativa de interpretação da gênese e evolução da infraestrutura arqueana exposta entre Peruíbe e Curitiba, SP e PR. In: SIMPÓSIO REGIONAL DE GEOLOGIA, 3., 1981. Curitiba. Atas. Curitiba: SBG, 1981.v.1, p. 133-147.

SILVA, A. T. S. F.; CHIODI FILHO, C.; CHIODI, D. K.; ALGARTE, J. P. Geologia Integrada das Folhas Cananéia e Iguape. In: CONGRESSO BRASILEIRO DE GEOLOGIA, 30., 1978. Recife. Anais... Recife: SBG, 1978. v.1, p. 208-221.

TASSINARI, C. C. G.; KAWASHITA, K.; VAN SCHMUS, R.; TAYLOR, P. N. As idades das rochas e dos eventos metamórficos da região sudeste do Estado de São Paulo. In: CONGRESSO BRASILEIRO DE GEOLOGIA, 35., 1988. Belém. Anais...Recife: SBG, 1988. v. 6, p. 2840-2853.

TUPINAMBÁ, M.; TEIXEIRA, W.; HEILBRON, M. (Neoproterozoic western Gondwana assembly and subduction-related plutonism: the role of the Rio Negro Complex in the Ribeira Belt. Revista Brasileira de Geociências, v. 30, n. 1, p. 7-11, 2000.

VASCONCELLOS, C. S.; DEHLER, N.; YAMATO, A. A.; LOPES, J. Projeto - Jacupiranga-Rio Guaraú. CPRM,
1999. 233 p. Relatório interno.

VIEIRA, S. R. S. S.; TASSINARI, C. C. G. Estudo petrológico e geocronológico das rochas da região de Embu-Guaçu, Estado de São Paulo. In: CONGRESSO BRASILEIRO DE GEOLOGIA, 35., 1988. Belém. Anais... Recife: SBG, 1988. v. 3, p. 1391-1399.

VLACH, S. R. Micropobe Monazite Constraints for an early (ca. 790 Ma) Brasiliano Orogeny: the Embu Terrane, Southeastern Brazil. In: SOUTH-AMERICAN SYMPOSIUMON ISOTOPE GEOLOGY, 3., 2001. Pucón. Extended Abstracts. Pucón: Sociedad Geológica de Chile, 2001. 1 CD-ROM.

WEBER, W. Geologia e Geocronologia da Ilha do Cardoso, Sudeste do Estado de São Paulo. São Paulo, 1998. 86f. Dissertação ( Mestrado) - Instituto de Geociências, Universidade de São Paulo, São Paulo. 